\title{
Dostopne in cenovno ugodne stanovanjske možnosti na ameriškem trgu zaplenjenih stanovanj: primer Tampe v okrožju Hillsborough na Floridi
}

Zaplemba in prodaja stanovanj sta bili med novejšo gospodarsko krizo resen problem $\mathrm{v}$ Združenih državah Amerike, saj sta močno vplivali na posameznike, gospodinjstva in skupnosti. Spodbujajo in izvajajo se različni programi za reševanje problema praznih stanovanj zaradi zaplemb, zgoščenih na enem območju. V članku se preučuje, kako bi lahko z zaplenjenimi stanovanji omogočili dostop do cenovno ugodnih stanovanj na mestnih območjih ZDA. Primerjane so prodajne cene zaplenjenih in nezaplenjenih stanovanj v Tampi na Floridi, nato pa so preučene štiri stanovanjske soseske in ugotavlja se, ali bi lahko nudile dostopna in cenovno ugodna stanovanja. Ugotovitve kažejo, da bi z zaplenjenimi stanovanji to $\mathrm{v}$ določeni meri lahko omogočili, čeprav na trgu ne dosegajo statistično pomembne nižje cene. Članek prispeva $\mathrm{k}$ trenutni razpravi o zaplembah, praznih stanovanjih in propadu sosesk, njegov namen pa je zlasti predstaviti posledice za stanovanjsko politiko na trgih z velikim številom praznih in nezadostnim številom cenovno dostopnih stanovanj. Poleg tega so v članku izpostavljene ovire, na katere bodo lahko lokalne skupnosti naletele pri preureditvi zaplenjenih stanovanj v cenovno dostopna stanovanja.

Ključne besede: cenovna dostopnost stanovanj, lastniška stanovanja, ameriški trg zaplenjenih stanovanj 


\section{Uvod}

Po krizi stanovanjskega in finančnega trga po drugem četrtletju leta 2007 so na milijone lastnikom zapadle hipoteke na stanovanjih, zaradi česar so morali zapustiti svoje domove ali naložbene nepremičnine (Wallison, 2009; Mehaffy in Haas, 2012). Posledica tega je veliko število praznih stanovanj in veliko družin, ki potrebujejo cenovno dostopno stanovanje. Članek se osredotoča na veliko zalogo praznih stanovanj v večstanovanjskih zgradbah (ang. condominiums), ki bi jih lahko po dostopni ceni ponudili družinam brez stanovanj.

Cenovno dostopna stanovanja bi bile stanovanjske enote, za katere mesečno ne bi plačevali več kot $30 \%$ bruto dohodka gospodinjstva; to je standard, ki ga je uvedlo ameriško ministrstvo za stanovanja in urbani razvoj (2010). Cenovno dostopna stanovanja bi v tem primeru namenili zlasti gospodinjstvom z nizkimi do srednje visokimi dohodki. $V$ članku se prvič preučuje, kako bi lahko prazna stanovanja zadovoljila potrebe mnogih družin po cenovno dostopnih stanovanjih, in sicer glede na cenovno strukturo in fizično obliko enote. Stanovanje je cenovno dostopno, če lahko posamezna družina s prihodki, ki ustrezajo nacionalnemu povprečju, pridobi hipoteko na stanovanju s povprečno ceno (nacionalno združenje nepremičninskih posrednikov, 2012). Meri se z indeksom cenovne dostopnosti stanovanj nacionalnega združenja nepremičninskih posrednikov.

\subsection{Ozadje}

Neredno odplačevanje hipotek in postopki zaplembe in prodaje stanovanj (ang. foreclosures) so začeli strmo naraščati po zlomu trga proti koncu prvega desetletja 21. stoletja. V zadnjem četrtletju leta 2006 je bilo neodplačano približno $0,54 \%$ vseh hipotekarnih posojil (2,00 \% drugorazrednih hipotekarnih posojil) in banke so začele postopek zaplembe nepremičnin. V zadnjem četrtletju leta 2007 je bilo neodplačano približno $0,83 \%$ vseh hipotekarnih posojil (3,44 \% konvencionalnih drugorazrednih hipotekarnih posojil), delež pa je do zadnjega četrtletja leta 2008 narasel na 1,08 \% (3,96 \% konvencionalnih drugorazrednih hipotekarnih posojil) oziroma na 1,40 \% (3,66\% konvencionalnih drugorazrednih hipotekarnih posojil) leta 2009. ${ }^{[1]}$ Dejavniki, ki prispevajo k postopku zaplembe, so prav tako postali kompleksnejši, saj so se med recesijo od nepremičninskih balonov in drugorazrednih hipotekarnih posojil premaknili k izgubam služb in brezposelnosti. Leta 2010 je bil postopek zaplembe sprožen še nad dvema milijonoma domov. Zaplembe imajo značilen geografski vzorec in se zgoščajo v južnem in severovzhodnem delu ZDA (ang. Sun Belt and Rust Belt states; Realtytrac, 2008). Čeprav ni znano, kaj natančno je povzročilo zgoščanje zaplemb na teh območjih, so h krizi na severovzhodu ZDA verjetno prispevala odpuščanja zaradi gospodarskega prestrukturiranja, na jugu ZDA pa močno povečanje števila novogradenj in nepremičninski baloni (Davies, 2010; Foote idr., 2010).

Florida je imela od leta 2006 enega največjih trgov zaplenjenih stanovanj, in sicer predvsem zaradi povečanja števila novogradenj med letoma 2001 in 2005, ko je bilo zgrajenih veliko večstanovanjskih zgradb z lastniškimi stanovanji ali pa so ta nastala $s$ preoblikovanjem hotelov in večstanovanjskih najemniških zgradb. Ker tovrstni projekti zahtevajo veliko časa, jih veliko ni bilo dokončanih vse do konca leta 2007 ali začetka leta 2008. Med velikim povečanjem števila novih stanovanj med letoma 2001 in 2005 si veliko prebivalcev Floride ni moglo privoščiti hiš zaradi prevelike razlike med inflacijo cen in realnimi prihodki, ki so za inflacijo zaostajali. Od julija 2001 do julija 2006 so cene stanovanj na Floridi narasle za $90 \%,{ }^{[2]} \mathrm{kar}$ je povzročilo zmanjšanje zaloge najemniških stanovanj, čeprav bi teoretično morala postati stanovanja zaradi zloma stanovanjskega trga cenejša. Na podlagi indeksa cenovne dostopnosti stanovanj nacionalnega združenja nepremičninskih posrednikov je zlom dosegel vrhunec leta 2009. Oteženo pridobivanje sredstev in omajana samozavest potrošnikov sta upočasnila nepremičninske transakcije, čeprav so bila stanovanja cenejša. Investitorji, špekulanti in lastniki večstanovanjskih zgradb so se po nepremičninskem zlomu leta 2006 po vsej državi soočali $z$ velikim številom praznih stanovanj, ki so preplavila trg. Med stanovanjsko in finančno krizo med letoma 2007 in 2009 je veliko posojilodajalcev zaprosilo za sprožitev postopka zaplembe stanovanj. Zaradi strožjih standardov odobritve posojil in nepripravljenosti posojilodajalcev, da odplačajo zapadle skupne stroške teh stanovanj pred začetkom postopka zaplembe in prodaje, je bila na trgu prodaje zaplenjenih stanovanj ponudba večja od povpraševanja, poleg tega pa so se v primerjavi s podobnimi zaplenjenimi nepremičninami ta stanovanja prodajala po nižji ceni. $V$ teh okoliščinah lahko na trenutno stanje gledamo na dva načina: 1. kot veliko krizo investitorjev, lastnikov nepremičnin, vlagateljev, sosesk in lokalnih skupnosti, ali pa 2. kot priložnost, da država in lokalne oblasti rešijo problem vse večje vrzeli pri cenovno dostopnih lastniških stanovanjih v številnih skupnostih na Floridi, saj je bilo veliko zaplenjenih stanovanj prodanih po občutno nižji ceni (Allen in Swisher, 2000; Immergluck in Smith, 2006a, 2006b; Lin idr., 2009). Poleg odbitka na davek za prvi nakup stanovanja in podaljšanega odbitka na davek za nakup drugega stanovanja so nepremičninske transakcije nekoliko ublažile problem presežne zaloge stanovanj. ${ }^{[3]}$ Florida je bila leta 2008 in 2009 četrta država v ZDA glede na davčni odbitek za prvi nakup stanovanja na prebivalca (White, 2009), kar potrjuje, da bi lahko recesija in zlasti zaplenjene hiše ponudile možnost nakupa družinam, ki si drugače ne bi mogle privoščiti svojega doma. Ker so tovrstne večstanovanjske zgradbe z lastniškimi stanovanji gosto pozida- 
ne in številne ter se nahajajo v predmestju oziroma mestu, bi zaradi nižje cene, možnosti nadstandardnih storitev, vključenih $\mathrm{v}$ ceni, in dostopnosti javnih dobrin lahko nudile cenovno dobro možnost nakupa stanovanja. Večina dosedanjih raziskav na to temo se osredotoča na negativne vplive zaplemb stanovanj, le malo pa jih obravnava priložnosti (na primer zagotavljanje cenovno dostopnih stanovanj), ki bi jih lahko ustvarila kriza.

Zalogi zaplenjenih zgradb, posebno večstanovanjskih, več ovir preprečuje, da bi gospodinjstvom s srednje visokimi prihodki nudila cenovno dostopne stanovanjske možnosti. Odbitki na davek za nakup prvega in drugega stanovanja so zapadli 30. aprila 2010. Obstajal je strah, da bi to upočasnilo nakupe in povzročilo dodaten padec cen nepremičnin leta 2010, preden si je gospodarstvo opomoglo od recesije. Po drugi strani je vse večja brezposelnost še naprej zavirala okrevanje gospodarstva. $\mathrm{Na}$ strani ponudbe so finančne ustanove poostrile dostop do posojil in standarde za odobritev hipotek, zaradi česar so kupci nepremičnin težje pridobili hipoteko. Niso samo prenehale uporabljati različnih eksotičnih finančnih orodij in oblikovati drugorazrednih hipotekarnih posojil, ampak so tudi občutno povišale pologe ter poostrile oceno kreditne sposobnosti in zahteve glede zaposlitve. Ko bodo državno sponzorirana podjetja prenehala kupovati hipoteke in jih spreminjati v hipotekarne vrednostne papirje, bo to močno prizadelo sekundarni hipotekarni trg. Trgi lastniških stanovanj so zlasti podvrženi strogim standardom odobritve posojil. Na spreminjanje lastniških stanovanj v cenovno dostopna stanovanja bodo negativno vplivali tudi različni dodatni stroški (na primer za vzdrževanje stavbe ali uporabe nadstandardnih storitev) in predpisi združenja lastnikov stanovanj (ang. condominium association).

Kupcev, ki kupujejo ta stanovanja posamično, je manj, več pa je kupcev, ki jih kupujejo na debelo kot naložbene nepremičnine. Če imajo na voljo dovolj naložbenega kapitala, zanje strog postopek odobritve posojila ni potreben. Ena od posledic kupovanja na debelo je zmanjšana ponudba stanovanj in s tem morebiten dvig cen stanovanj in najemnin. Strogi standardi odobritve posojil ne bodo prizadeli kupcev na debelo, temveč zlasti gospodinjstva s srednje visokimi prihodki in gospodinjstva $\mathrm{z}$ omejenimi prihranki za plačilo are, ki želijo kupiti stanovanje v večstanovanjski zgradbi.

Drugorazredni krediti, postopki zaplembe in prodaje stanovanj ter njihov vpliv na soseske in vrednost nepremičnin so v literaturi razmeroma dobro obravnavani, malo raziskav pa obravnava samo zaplembe. Vse se namreč osredotočajo le na enodružinske hiše, nobena pa ne obravnava zaplemb, povezanih z drugimi vrstami stanovanj, zlasti lastniškimi stanovanji v večstanovanjskih zgradbah. Razlog za to je verjetno pomanjkanje zanesljivih podatkov o zaplembah teh stanovanj in dejstvo, da posojilodajalci niso pripravljeni zapleniti stanovanj tistim posameznikom, ki zamujajo s plačilom posojila, saj bi morali plačati stroške združenja lastnikov stanovanj. Članek poskuša zapolniti to raziskovalno vrzel in zaplembe razumeti kot priložnost ter raziskati možnost preoblikovanja stanovanj $\mathrm{v}$ večstanovanjskih zgradbah v cenovno dostopna stanovanja $s$ premagovanjem ovir. $\mathrm{V}$ ta namen je bil preučen vzorec stanovanj, ki so bila leta 2008 prodana v floridskem okrožju Hillsborough (v mestu Tampa) in so bila med gospodarsko recesijo v postopku zaplembe. Te transakcije so bile izpeljane kot (a) posli na podlagi strogih poslovnih odnosov (ang. arms-length transactions), (b) transakcije, pri katerih je bila nepremičnina $\mathrm{v}$ lasti banke, ali (c) transakcije, ki naj bi preprečile zaplembo. $\mathrm{V}$ članku se obravnavajo ta raziskovalna vprašanja: 1. ali so prodajne cene stanovanj, ki so v lasti banke ali se prodajajo kratkoročno (ang. short sale), primerljive s kvalificiranimi transakcijami za stanovanja, ki se prodajajo na trgu, in kakšen je razpon cen teh stanovanj, in 2. kakšne so možnosti, da kriza, povezana z zaplembami stanovanj, pomaga zmanjšati potrebe po cenovno dostopnih stanovanjih? ${ }^{[4]}$

V članku so najprej na kratko predstavljene dosedanje raziskave trga zaplenjenih stanovanj oziroma zlasti trga lastniških stanovanj. Nato je preučena povezava med cenovno dostopnimi stanovanji in trgom lastniških stanovanj (zlasti trg zaplenjenih lastniških stanovanj), in sicer so preučeni klasični cenovni modeli lastniških stanovanj in kako lahko ta stanovanja (zlasti tista, ki so v postopku zaplembe) postanejo cenovno dostopna. Temu sledi opis uporabljenih podatkov, metodologije in rezultatov. Članek konča obravnava mogočih načrtovalskih rešitev $\mathrm{v}$ prihodnosti.

\subsection{Trg zaplenjenih stanovanj}

Zaplenjene nepremičnine se običajno prodajajo po nižji ceni kot druge podobne nepremičnine $\mathrm{v}$ isti ali bližnjih soseskah (Forgey, 1994; Carroll idr., 1995). Nepremičnine je zaplenila zvezna stanovanjska uprava (ang. Federal Housing Administration, v nadaljevanju: FHA) in tudi druge nepremičnine v soseskah, $\mathrm{v}$ katerih je določene nepremičnine zaplenila FHA, se navadno prodajajo po precej nižji ceni kot nepremičnine, kupljene s klasičnimi posojili. Neučinkovito trženje ameriškega ministrstva za stanovanja in urbani razvoj (ang. US Department of Housing and Urban Development, v nadaljevanju: HUD), prodaja teh stanovanj v stanju, v kakršnem so, torej že dolgo prazna in $\mathrm{v}$ problematičnih soseskah, in predsodki kupcev do nepremičnin FHA povzročajo, da se nepremičnine, ki jih zavaruje FHA, prodajajo po nižji ceni (Carroll idr., 1995). Anthony Pennington-Cross (2003) navaja, da so se nepremičnine, ki so bile zaplenjene kmalu po nakupu zaradi neodplačevanja dolgov, prodajale po najnižji ceni in da se nepremičnine v zveznih državah, v katerih se zahteva sodni postopek zaplembe in prodaje stanovanj, prodajajo po nižji ceni kot v zveznih državah, $v$ 
katerih sodni postopek ni potreben. Prav tako je ugotovil, da natančnejša ocena nepremičnin, kupljenih s posojilom z nižǰim pologom, vodi $\mathrm{k}$ višji ceni pri prodaji zaplenjene nepremičnine. Nižja cena samo ene zaplenjene nepremičnine vpliva na celotno vrednost nepremičnin, skupina tovrstnih nepremičnin pa ta vpliv le še pomnoži (Schuetz idr., 2008; Harding idr., 2009).

Poleg tržne cene zaplenjenih nepremičnin je nekaj raziskovalcev preučevalo tudi mehanizem oblikovanja cen zaplenjenih nepremičnin na dražbi. Cene zaplenjenih nepremičnin, dosežene na dražbi, so običajno nižje kot zaplenjene nepremičnine, ki se prodajajo na prostem trgu. Marcus T. Allen in Judith Swisher (2000) navajata, da so se nepremičnine, ki jih je HUD prodajalo na dražbi, prodajale po ceni, ki je bila nižja od njihove napovedane tržne vrednosti (v povprečju je bila cena za $17,45 \%$ nižja od napovedane tržne vrednosti), čeprav to ne pomeni, da so hiše, ki jih HUD prodaja na dražbi, v problematičnih soseskah. Prav tako menita, da je lahko nižja cena geografsko pogojena. Kot navajata, je bila cena v južni Floridi najnižja na zahodni obali, najvišja pa v okrožju Miami-Dade. Raziskavo sta izvajala, ko je bil nepremičninski trg stabilen, zaradi česar so pri mehanizmu dražb lahko določene razlike v primerjavi s trenutno finančno in stanovanjsko krizo.

Izsledki raziskav kažejo, da so se zaplenjene nepremičnine na splošno prodajale po nižji ceni, čeprav se je obseg znižanja cene razlikoval glede na trg in posamezno raziskavo (Shilling idr., 1990; Forgey idr., 1994; Carroll idr., 1995; Hardin in Wolverton, 1996; Allen in Swisher, 2000; Immergluck in Smith, 2006a). Obseg znižanja cene določa zlasti motivacija prodajalca in pripravljenost posojilodajalca, ki je lastnik nepremičnine, da sprejme nižjo likvidacijsko vrednost in tako nepremičnino hitreje proda (Shilling idr., 1990). Le malo raziskovalcev pa je preučevalo obseg znižane cene na podlagi različnih geografskih trgov in vrst nepremičnin, čeprav sta William G. Hardin in Marvin L. Wolverton (1996) ugotovila, da so se zaplenjeni stanovanjski kompleksi prodajali po $22 \%$ nižji ceni kot nezaplenjena stanovanja. Doslej še ni bilo raziskano, ali se zaplenjena stanovanja prodajajo po nižji ceni kot druge vrste stanovanj, kar bi ljudem omogočilo, da kupijo stanovanje po ugodni ceni.

Zaplenjena stanovanja so bila prodana po nižji ceni, in sicer ne glede na to, ali je šlo za kratke prodaje (ang. short sales), prodaje na dražbi ali prodaje stanovanj v lasti banke. Poleg tega se nepremičnine, ki so v postopku zaplembe, prodajajo hitreje kot nepremičnine v normalnih pogojih (Springer, 1996), in sicer zlasti med stanovanjsko krizo, ko gre pri velikem delu transakcij stanovanjskih nepremičnin za zaplembe. Vendar je od prošnje za sprožitev postopka zaplembe do dražbe in prodaje $s$ strani banke običajno preteklo ogromno časa, zaradi česar so bile problematične nepremičnine prodane pozno. $V$ povprečju traja približno 28 mesecev, preden zaplenjena nepremičnina postane last banke (ang. real estate owned property), in še šest mesecev, preden se tudi proda (Pennington-Cross, 2003).

\subsection{Cenovno dostopno lastništvo stanovanj in stanovanja v večstanovanjskih zgradbah}

Čeprav obstajajo številni načini dostopa do cenovno ugodnih stanovanj, je to še vedno velik problem v mnogih delih države, zlasti če cene stanovanj skokovito narastejo, povprečni prihodek gospodinjstva pa temu ne sledi. Pomanjkanje cenovno dostopnih stanovanj je posledica neravnovesja na nepremičninskem trgu, na katerem ponudba in povpraševanje nista dobro uravnotežena. Med stanovanjskim in gospodarskim razcvetom sta velik dobiček in pomanjkanje določenih vrst stanovanj v številnih južnih zveznih državah pospešila novogradnje in spodbudila preoblikovanje najemnih večstanovanjskih zgradb $\mathrm{v}$ lastniške večstanovanjske zgradbe. To je povzročilo presežno ponudbo in slabo prodajo stanovanjskega fonda. Ko je stanovanjski balon počil, bi lahko lastniška stanovanja zaradi upada cen stanovanj postala cenejša, če bi bili gospodarski pogoji stabilnejši.

Stanovanja se lahko pocenijo z vidika ponudbe in tudi povpraševanja (Nelson, 1994). Davčni odbitki pri nakupu stanovanja zaradi nizkega dohodka, občinski zemljiški skladi, nepremičnine, ki jih posameznik kupi skupaj z drugim vlagateljem (običajno državo ali neprofitno organizacijo), in stanovanjske subvencije, kot sta pomoč pri odplačilu are in izdaja stanovanjskih bonov za pomoč pri plačevanju najemnin, so na nekaterih območjih pomagali reševati krizo na področju cenovno dostopnih stanovanj. Vse te metode pa imajo svoje omejitve. Z večstanovanjskimi zgradbami z lastniškimi stanovanji in hišami v mestu so dejavno pomagali zagotoviti cenovno ugodna stanovanja, saj so njihove cene navadno nižje od primerljivih enodružinskih hiš. To zlasti velja za dinamične nepremičninske trge, na katerih vlada veliko povpraševanje, na primer v Nevadi, Kaliforniji, na Floridi, v Washingtonu in New Yorku. Večina večstanovanjskih stavb je blizu mestnega središča $\mathrm{z}$ dobrim dostopom do delovnih mest in javnega prevoza. Na splošno lastniške in najemne večstanovanjske stavbe nudijo cenovno ugodne možnosti zaradi lokacije in goste pozidave.

Med gospodarsko in finančno krizo, ki se je začela leta 2007, je ameriški kongres, da bi ohranil zalogo cenovno dostopnih stanovanj, sprejel zakon o nacionalnem skrbniškem skladu za cenovno dostopna stanovanja (ang. National Affordable Housing Trust Fund Act). Mnogi so menili, da bi lahko prazne zaplenjene nepremičnine z inovacijami, kot so partnerstva in programi kupovanja praznih zemljišč $s$ strani javne ali zasebne ustanove, uspešno preoblikovali v cenovno dostopna stanovanja (Carr, 2008; Poethig, 2010). Cene hiš so dejansko padle, vendar s tem problem cenovno dostopnih stanovanj na 
Floridi še ni bil rešen. Februarja 2009 je bilo tam približno 750.000 družin še vedno brez stanovanja, ki bi si ga lahko privoščile (Padgett, 2009). Naraščajoče število gospodinjstev, ki so jim zaplenili stanovanje, in vse več družin brez stanovanja je močno obremenilo trg najemnih stanovanj in zalogo cenovno dostopnih stanovanj. Zaradi strožjih standardov odobritve hipotek in težav pri pridobivanju posojil so ta gospodinjstva še težje prišla do stanovanja, čeprav so bile cene nizke.

Lastniška stanovanja je močno prizadela stanovanjska in finančna kriza med letoma 2007 in 2009. Med letoma 2003 in 2008 je bilo v središč Miamija zgrajenih oziroma predelanih 23.000 lastniških stanovanj, vendar jih je stanovalce imelo samo 13.000 (House Repos, 2009). Čeprav ni jasno, koliko stanovanj je bilo zaplenjeno, se tudi te nepremičnine niso izognile gospodarski krizi. O zaplenjenih nepremičninah je na voljo presenetljivo malo podatkov, razen tistih, ki jih imajo določena pridobitna nepremičninska podjetja, kot je Condo Vultures, Inc. Velik del zaplenjenih domov so lastniška stanovanja na Floridi in v New Yorku, kjer je delež tovrstnih stanovanj v stanovanjskem fondu precejšen. $V$ znanstveni literaturi ni primera, ki bi obravnaval zaplembe lastniških stanovanj, njihove posledice in to, ali trg zaplenjenih stanovanj nudi dobre možnosti za arbitražo in špekulacijo. Poleg tega strogi standardi odobritve posojil za nakup stanovanj vodijo v nižje cene $\mathrm{v}$ primerjavi z drugimi vrstami stanovanjskih objektov. Število zaplenjenih stanovanj, ki se prodajajo na trgu, je lahko celo večje od števila drugih vrst zaplenjenih stanovanjskih objektov, zaradi česar bi lahko velik delež praznih stanovanj ostal neprodan. Ta počasni trg zaplenjenih stanovanj zahteva spremembe $v$ politiki, ki bi omogočile ponovno rabo teh nepremičnin. Preoblikovanje lastniških stanovanj v cenovno dostopne stanovanjske oblike kot inovativna strategija stabilizacije soseske se sooča z različnimi problemi, kot so nezadostni viri financiranja in konkurenca vlagateljev, ki taka stanovanja kupujejo na debelo (Gerrity, 2010). Uspešno preoblikovanje teh stanovanj zahteva dobro javno-zasebno partnerstvo. Program stabilizacije soseske ne more zapolniti vrzeli med potrebami po cenovno dostopnih stanovanjih in razpoložljivimi cenovno dostopnimi domovi. Na primer v mestu Lawrence v zvezni državi Massachusetts sta predelava in obnova štirih zgodovinskih večstanovanjskih zgradb temeljili predvsem na sodelovanju med neprofitno organizacijo Lawrence Community Works, mestno občino Lawrence, državo Massachusetts, zasebno organizacijo Massachusetts Housing Investment Corporation, Enterprise Bank in mrežo NeighborWorks America (Betances, 2010).

V New Yorku, kjer so cenovno dostopna stanovanja večni problem, mnogi podpirajo predelavo praznih luksuznih stanovanj v cenovno dostopna stanovanja; nekatera taka luksuzna stanovanja so bila med stanovanjskim razcvetom zgrajena celo $\mathrm{v}$ soseskah, v katerih živijo ljudje z nižjiimi dohodki (Katz,
2009). Po podatkih zveze za pravico do mesta (ang. Right to the City Alliance, 2010) je v šestih newyorških okrožjih približno 4.092 praznih stanovanj, zato je to leta 2010 predlagalo, naj se nekatera preoblikujejo v cenovno dostopna stanovanja. Leta 2009 je mesto namenilo 20 milijonov USD občinskih sredstev za preoblikovanje 400 stanovanj v cenovno dostopna stanovanja. Če bo pilotni projekt uspel, mu bo sledilo še več tovrstnih projektov (House Repos, 2009). Da bi se mestna občina New York izognila konkurenci zasebnih kupcev stanovanj, se bo najverjetneje osredotočila na predelavo cenejših in manj konkurenčnih manjših večstanovanjskih zgradb v cenovno dostopna stanovanja (Anderson, 2010). Kljub temu tovrstne pobude na Floridi niso bile uspešne, saj so tam prazna stanovanja še vedno velik problem.

\section{Gradivo in metodologija}

V članku se poskuša odgovoriti na dve vprašanji: 1. ali so prodajne cene stanovanj, ki so v lasti banke ali se prodajajo kratkoročno, primerljive $s$ kvalificiranimi transakcijami za stanovanja, ki se prodajajo na trgu, in kakšen je razpon cen teh stanovanj, in 2. kakšne so možnosti, da kriza, povezana z zaplembami stanovanj, pomaga zmanjšati potrebe po cenovno dostopnih stanovanjih.

$\mathrm{V}$ raziskavi smo uporabili kvantitativne in kvalitativne metode. Najprej smo izvedli prečno analizo z uporabo multivariatne regresije in preučili odnos med oblikovanjem cen lastniških stanovanj in stanjem transakcije na nepremičnini, da bi ugotovili, ali so zaplenjena stanovanja povezana z nižjimi prodajnimi cenami in kako cenovno dostopna so bila za gospodinjstva z nizkimi do srednjimi prihodki. Nato smo izvedli kvalitativno študijo in preučili, kako so se transakcije na zaplenjenih nepremičninah povezovale z zagotavljanjem cenovno dostopnih stanovanj. Ti metodi smo uporabili za reševanje zgoraj predstavljenih raziskovalnih vprašanj.

S tržno vrednostjo lastniških stanovanj smo ocenili dejavnike, ki vplivajo na oblikovanje cen. Raziskava je temeljila na podatkih o prodajnih cenah nepremičnin iz leta 2008, ki smo jih pridobili iz arhiva obdavčljivih nepremičnin floridske davčne uprave (ang. Florida Department of Revenue, v nadaljevanju: FL-DOR), in demografskih podatkih ameriškega popisnega urada. FL-DOR vsako leto objavi prodajne cene za vse nepremičninske transakcije na Floridi, ki jim jih sporočijo lokalni okrožni nepremičninski cenilci. Prodajne cene nepremičnin smo združili z informacijami o posameznih parcelah $\mathrm{v}$ geografskem informacijskem sistemu (GIS), s čimer smo določili splošne lokacije nepremičnin, in s podatki iz ameriškega popisa leta 2008, s čimer smo preverjali demografske dejavnike. 
$\mathrm{V}$ prvem delu raziskave smo uporabili ta prečni model multivariatne regresije (model 1):

Prodajna cena $=\mathrm{B}_{0}+\mathrm{B}_{1}($ bivalna poursina $)+\mathrm{B}_{2}($ leto gradnje $)+$ $\mathrm{B}_{3}$ (oddaljenost od poslovnega središca $)+\mathrm{B}_{4}$ (oddaljenost od obale $)+\mathrm{B}_{5}($ davina pristojnost $)+\mathrm{B}_{6}($ rasa $)+$ $\mathrm{B}_{7}($ najem/lastnistvo $)+\mathrm{B}_{8}($ srednje visoki dohodki $)+$ $\mathrm{B}_{9}($ status transakcije $)+\mathrm{B}_{10}($ mesec transakcije $)+\mathrm{e}$

$\mathrm{V}$ preglednici 1 so na kratko našteti in opisani vse preučevane spremenljivke in viri podatkov. $V$ preglednici 2 so predstavljeni opisni statistični podatki. Odvisna spremenljivka v tem delu raziskave je bila prodajna cena posameznih stanovanjskih enot v Tampi na Floridi (okrožje Hillsborough). Vseh izpeljanih opazovanj v preučevanem vzorcu je bilo $254 .{ }^{[5]} 80$ \% (203) opazovanj je bilo izvedeno na območjih zunaj mestne občine Tampa, medtem ko jih je bilo na območju mestne občine izvedeno 17 \% (43). Poleg tega je bilo 3 \% (8) opazovanj izvedeno $v$ mestni občini Temple Terrace, ki je ena od treh mestnih občin v okrožju Hillsborough. Izbrali smo primerno območje preučevanja, saj gre za srednje veliko metropolitansko območje $s$ predmestji, kar omogoča, da rezultate posplošimo na prebivalstvo podobnih mest na Floridi in v celotnih ZDA. ${ }^{[6]}$ Prodajne cene stanovanj, vključenih v model, so se gibale med 10.000 in 567.000 USD, pri čemer je središčna vrednost (mediana) prodajne cene znašala 278.500 USD. Povprečna prodajna cena je znašala 89.628 USD s standardnim odklonom 61.212 USD. Za primerjavo: povprečna prodajna cena enodružinskih hiš na tem območju je v enakem obdobju znašala 192.762 USD s standardnim odklonom 101.745 USD (dejanski razpon cen je znašal od 14.000 do 565.000 USD; $N=2.107$ ).

Za preverjanje sezonskosti transakcij smo vključili tudi mesec transakcije. Gre za slamnato spremenljivko, ki temelji na mesecu prodaje. V raziskavo smo vključili mesece od januarja (1) do maja (5). Ta časovni okvir ponuja prečni prerez prve zimsko/ pomladne sezone po zlomu nepremičninskega in finančnega trga leta $2007 .{ }^{[7]}$

Kontrolni spremenljivki, uporabljeni pri analizi, sta bili bivalna površina in starost stanovanja. Medtem ko lahko druge lastnosti stanovanj vplivajo na prodajno ceno in se jih lahko prav tako upošteva pri raziskavi, ti spremenljivki omogočata preverjanje levjega deleža lastnosti posameznega stanovanja, kot so število spalnic ali osnovni arhitekturni trendi v preučevanem obdobju. Lokacijske kontrolne spremenljivke soseske, uporabljene $\mathrm{v}$ analizi, so bile oddaljenost doma od poslovnega središča, oddaljenost od obale in davčna pristojnost. Te spremenljivke so bile namenjene preverjanju dnevne migracije $\mathrm{v}$ mestno središč in do rekreacije na vodi, kot tudi preverjanju opravljene davčne storitve oziroma plačane pristojbine. $\mathrm{V}$ analizo so bile poleg tega vključene tudi značilnosti iz popisa prebivalstva, kot so rasa (delež nebelcev), povprečni dohodek in delež lastnikov stanovanj, s katerimi smo preverjali splošne demografske lastnosti soseske. Standardne napake smo združili glede na najmanjšo geografsko enoto popisa (ang. census block), saj smo želeli upoštevati regionalne vplive, ki so značilni za določeno sosesko, in vpliv soseske na prodajno ceno stanovanja. »Status transakcije«, ključna neodvisna spremenljivka, je bila slamnata spremenljivka, ki je pokazala, ali je bilo stanovanje ob prodaji v postopku zaplembe.

\subsection{Transformacije na podlagi diagnostike}

$\mathrm{Na}$ podlagi diagnostike rezultatov regresije navadnih najmanjših kvadratov smo transformirali dva modela. Najprej je histogram odvisne spremenljivke (prodajne cene) pokazal, da je vzorec pozitivno asimetričen. Uporabili smo navodila za transformacijo te spremenljivke $\mathrm{v}$ logaritemsko obliko za namene analize. Poleg tega smo uporabili tudi Box-Coxovo transformacijo, $s$ katero smo dobili podobne rezultate. Drugič, spremenljivko »leto gradnje « smo transformirali v kvadrirano

Preglednica 1: Opis spremenljivk

\begin{tabular}{ll}
\hline Spremenljivka & Opis \\
\hline prodajna cena (o. s.) & vrednost nepremičninske transakcije v ameriških dolarjih (USD) na stanovanje \\
\hline bivalna površina & skupna notranja bivalna površina v kvadratnih metrih \\
\hline leto gradnje & leto, v katerem je bilo stanovanje izgrajeno \\
\hline oddaljenost od poslovnega središča & oddaljenost parcele od središčne točke v mestu (Tampa) v metrih \\
\hline oddaljenost od obale & oddaljenost parcele od najbližje obale v metrih \\
\hline pristojnost & $\begin{array}{l}\text { slamnata spremenljivka za davčno pristojnost (Tampa, Temple Terrace in zunajmestno območje } \\
\text { okrožja Hillsborough) }\end{array}$ \\
\hline rasa & delež nebelcev \\
\hline najemnik/lastnik & delež lastnikov stanovanj na najmanjšo popisno enoto \\
\hline povprečni dohodek & povprečni dohodek (v USD) na najmanjšo popisno enoto \\
\hline status transakcije & slamnata spremenljivka, ki kaže, ali je bila nepremičnina v postopku zaplembe, ko se je prodajala \\
\hline mesec & mesec zabeležene nepremičninske transakcije \\
\hline
\end{tabular}

Opomba: (o. s.) = odvisna spremenljivka 
Preglednica 2: Opisni statistični podatki

\begin{tabular}{lll}
\hline Spremenljivka & Obseg/opis & Povprečje (standardni odklon) ali delež (pogostnost) \\
\hline prodajna cena & $10.000-567.000$ USD & 89.628 USD $(61.212$ USD) \\
\hline bivalna površina & $31,59-253,25 \mathrm{~m}^{2}$ & $120,31 \mathrm{~m}^{2}\left(37,44 \mathrm{~m}^{2}\right)$ \\
\hline leto gradnje & $1969-2008$ & $1990(11)$ \\
\hline oddaljenost od posl. središča & $7.735,82-30.486,71 \mathrm{~m}$ & $21.058,33 \mathrm{~m}(7.033,56 \mathrm{~m})$ \\
\hline oddaljenost od obale & $8,53-23.535,13 \mathrm{~m}$ & $9.291,83 \mathrm{~m}(5.438,55 \mathrm{~m})$ \\
\hline \multirow{3}{*}{ pristojnost } & Tampa & $17 \%(43)$ \\
\cline { 2 - 3 } & Temple Terrace & $3 \%(8)$ \\
\cline { 2 - 3 } rasa & okrožje Hillsborough & $80 \%(203)$ \\
\hline najemnik/lastnik & $27-99 \%$ & $77 \%(18 \%)$ \\
\hline povprečni dohodek & $1-98 \%$ & $68 \%(31 \%)$ \\
\hline \multirow{2}{*}{ status transakcije } & $23.937-126.438$ USD & 52.032 USD (20.386 USD) \\
\hline & ni v postopku zaplemb/kvalificirana transakcija* & $90 \%(229)$ \\
\cline { 2 - 3 } & v postopku zaplembe & $10 \%(25)$ \\
\hline \multirow{2}{*}{ mesec } & januar & $11 \%(29)$ \\
\cline { 2 - 3 } & februar & $16 \%(40)$ \\
\cline { 2 - 3 } & marec & $20 \%(50)$ \\
\cline { 2 - 3 } & april & $32 \%(82)$ \\
\cline { 2 - 3 } & maj & $21 \%(53)$ \\
\hline
\end{tabular}

Opombe: $N$ = 254; vse številke so zaokrožene na najbližje celo število; $\left.{ }^{*}\right)$ referenčna kategorija.

vrednost starosti, da smo lahko upoštevali nelinearne učinke starosti na ceno stanovanj. Druge transformacije niso bile smiselne, prav tako nismo opazili drugih problemov.

\section{Rezultati}

\subsection{Oblikovanje cen stanovanj in status nepremičninske transakcije}

Neodvisne spremenljivke v prvem modelu so pojasnile $68 \%$ variacije v prodajnih cenah stanovanjskih transakcij v okrožju Hillsborough med januarjem in majem 2008. To je že nakazalo povezavo med transakcijami v postopku zaplembe in prodajnimi cenami. Kot smo pričakovali, so bila stanovanja v postopku zaplembe negativno povezana s prodajnimi cenami, kljub temu nižje cene niso bile statistično pomembne. $V$ preglednici 3 so predstavljeni rezultati regresije pri modelu 1 . Stanovanja v mestni občini Tampa so bila statistično pomembno pozitivno povezana s prodajnimi cenami na ravni alfa $0,01(0,252 ; 0,089)$.

Pri prvem modelu je bil status transakcije binarna slamnata spremenljivka, ki se je nanašala na to, ali je bilo stanovanje ob prodaji v postopku zaplembe. $V$ tem vzorcu je postopek zaplembe zajemal vse transakcije, zabeležene kot 1. prenos lastništva na finančno ustanovo ali obratno (stanovanje v lasti banke) ali 2. transakcije v izjemnih okoliščinah (transakcije, ki jim je grozila zaplemba banke). Razlika je bila v tem, da je bilo v prvem primeru stanovanje v lasti banke in je bilo zaplenjeno, $v$ drugem primeru pa se je postopek zaplembe začel,
Preglednica 3: Rezultati regresije pri modelu 1

\begin{tabular}{ll}
\hline Spremenljivka & $\begin{array}{l}\text { Koeficienti } \\
\text { (robustna standardna napaka) }\end{array}$ \\
\hline bivalna površina & $\begin{array}{l}0,001^{* * *} \\
(0,00009)\end{array}$ \\
\hline starost (kvadrirana) & $\begin{array}{l}-0,0002^{*} \\
(0,0001)\end{array}$ \\
\hline oddaljenost od posl. središča & $-5,91^{*}$ \\
& $(3,07)$ \\
\hline oddaljenost od obale & $-5,84^{* *}$ \\
& $(2,86)$ \\
\hline rasa & $0,948^{* *}$ \\
& $(0,4)$ \\
\hline najemnik/lastnik & $-0,267^{*}$ \\
\hline povprečni dohodek & $(0,16)$ \\
\hline transakcija v postopku & $-2,61$ \\
zaplembe & $(1,35)$ \\
\hline prilagojeni $R$-kvadrat & $-0,076$ \\
(ver. $>F=0,000)$ & $(0,085)$ \\
\hline
\end{tabular}

Opombe: $N=254 ;\left(^{*}\right) p<0,1,\left({ }^{* *}\right) p<0,05,\left({ }^{* * *}\right) p<0,01,(* * * *)$ $p<0,001$

vendar še ni bil dokončan. Vse druge transakcije v vzorcu smo obravnavali kot transakcije, ki niso v postopku zaplembe. Pri drugem modelu smo transakcije v lasti banke in transakcije pod pritiskom banke za potrebe analize ločili. Ti dodatni opisni statistični podatki so prikazani v preglednici 4 . 
Preglednica 4: Opisni statistični podatki za transakcije v lasti banke in transakcije pod pritiskom banke

\begin{tabular}{lll}
\hline Spremenljivka & Opis & Delež (pogostnost) \\
\hline \multirow{3}{*}{ transakcija } & ni v postopku zaplembe & $90 \%(229)$ \\
\cline { 2 - 3 } & $\begin{array}{l}\text { v postopku zaplembe/v lasti } \\
\text { banke }\end{array}$ & $7,5 \%(19)$ \\
\cline { 2 - 3 } & $\begin{array}{l}\text { v postopku zaplembe/pod } \\
\text { pritiskom banke }\end{array}$ & $2,5 \%(6)$ \\
\hline
\end{tabular}

Opombe: $N=254$; vse številke so zaokrožene na najbližje celo število.

Ko smo spremenljivko transakcije ločili na dva dela, se je izkazalo, da so se stanovanja $\mathrm{v}$ lasti banke prodajala po statistično pomembno nižji ceni (raven alfa 0,05 ). Rezultati regresije transakcij pri modelu 2 so prikazani v preglednici 5 .

Preglednica 5: Rezultati regresije transakcij pri modelu 2

\begin{tabular}{lll}
\hline Spremenljivka & Opis & $\begin{array}{l}\text { Koeficienti } \\
\text { (robustna standardna } \\
\text { napaka) }\end{array}$ \\
\hline \multirow{3}{*}{ transakcija } & v postopku zaplembe/v & $\begin{array}{l}-0,185^{*} \\
\end{array}$ \\
\cline { 2 - 3 } & lasti banke & $(0,088)$ \\
\cline { 2 - 3 } & v postopku zaplembe/ & 0,244 \\
& pod pritiskom banke & $(0,161)$ \\
\hline
\end{tabular}

Opombe: $N=254 ;\left(^{*}\right) \mathrm{p}<0,05$
Tako se zdi, da bi bila lahko stanovanja v lasti banke primeren vir cenovno dostopnih stanovanj. To se sklada tudi s pričakovanji. Rezultati regresije so nam dali okvirno sliko transakcij stanovanjskih nepremičnin, ki so bila ali pa niso bila v postopku zaplembe, vendar so nam razkrili le malo značilnosti stanovanj in podatkov o tem, ali bi bila lahko primeren vir cenovno dostopnih stanovanj. Zato smo stanovanja $\mathrm{v}$ lasti banke ocenili tudi kvalitativno, saj smo želeli dodatno preveriti, ali so ta znižana stanovanja primeren vir cenovno dostopnih stanovanj.

\subsection{Prodaja zaplenjenih stanovanj in zagotavljanje cenovno dostopnih stanovanj}

Padec cen nepremičnin zaradi nepremičninske in finančne krize je ustvaril dobre priložnosti za nakup cenovno ugodnih stanovanj, vendar so strožji standardi odobritve posojil in manjša potrošnja povzročili druge težave na stanovanjskem področju. V okrožju Hillsborough so se stanovanjski stroški močno povečali (glej sliko 1), saj so gospodinjstva več kot $50 \%$ svojega dohodka porabila za stanovanja in podobne stroške. Leta 2008 so se stroški močno povečali približno 49.166 gospodinjstvom, katerih dohodek je znašal manj kot 80 \% povprečnega dohodka območja (ang. Area Median Income, v nadaljevanju: AMI); to število naj bi do leta 2030 naraslo na 68.537. Med temi gospodinjstvi je bilo $16 \%$ najemniških gospodinjstev in $8 \%$

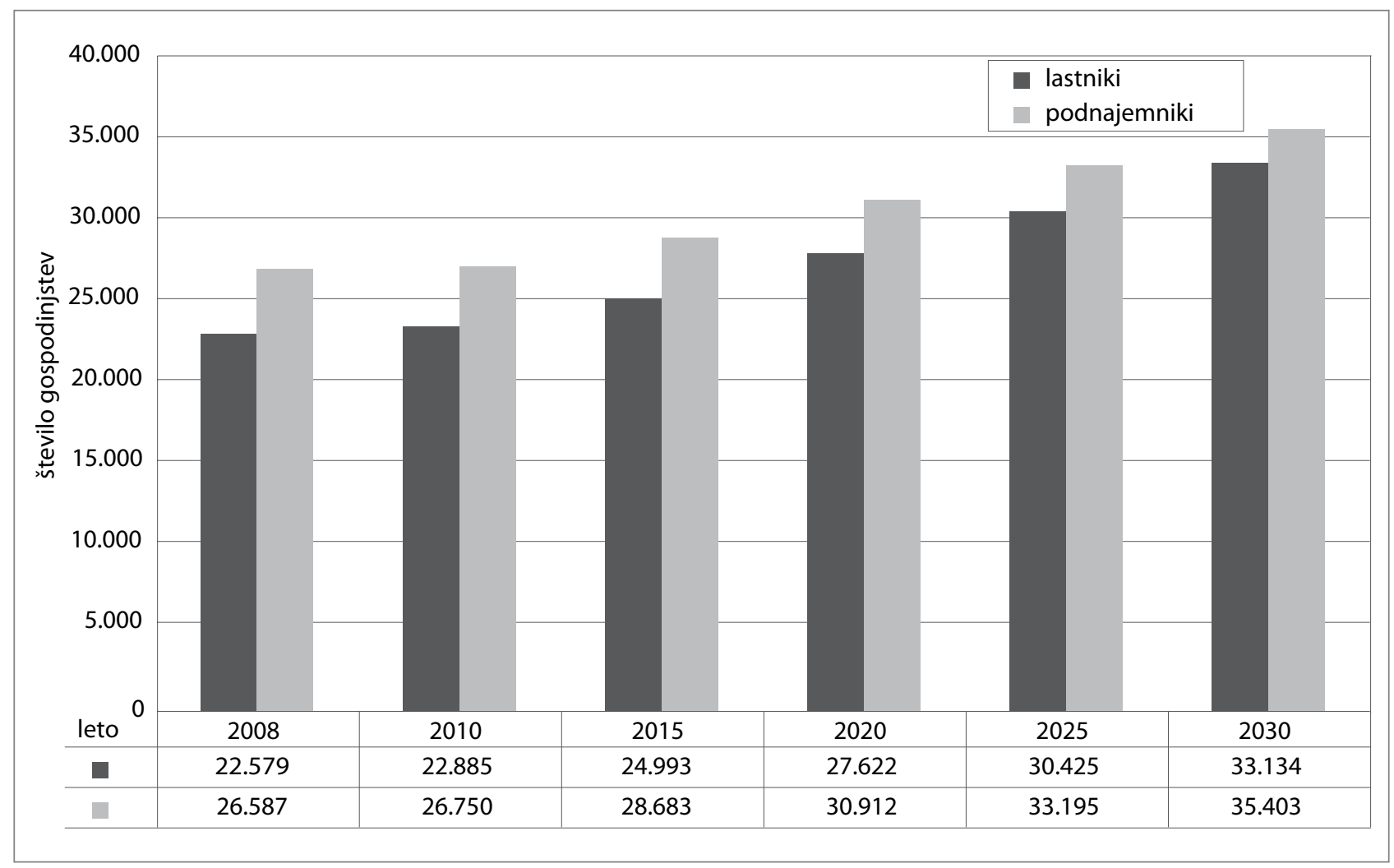

Slika 1: Število stroškovno močno obremenjenih gospodinjstev (50 \% in več), katerih dohodek znaša manj kot 80 \% AMI glede na lastništvo v okrožju Hillsborough na Floridi, v obdobju 2008-2030 (vir: floridska klirinška hiša za nepremičninske informacije, 2010). 
gospodinjstev z lastniškimi stanovanji v okrožju Hillsborough. Višji stroški so še zlasti prizadeli najemnike. V okrožju Hillsborough se je število močno obremenjenih gospodinjstev precej povečalo v primerjavi z mnogimi drugimi okrožji na Floridi, kar je povzročilo velike potrebe po cenovno dostopnih stanovanjih (floridska klirinška hiša za nepremičninske informacije, 2010). Analiza z uporabo modelov multivariatne regresije je pokazala, da se je cena prodaje zaplenjenih stanovanj v okrožju Hillsborough razmeroma malo znižala, kar je povzročalo dodatne težave pri predelavi zaplenjenih domov, zlasti lastniških stanovanj, v cenovno dostopna stanovanja.

\subsection{Zaplemba in prodaja stanovanj in zagotavljanje cenovno dostopnih stanovanj}

V preučevanem obdobju je bilo v okrožju Hillsborough prodano 258 stanovanj. Te transakcije pa niso bile nujno sklenjene na dražbi ali kot prodaja stanovanj, katerih lastnik je že postala banka. Raziskavo smo nato nadaljevali z oceno stanovanjskih transakcij in zaplemb ter tega, kakšne priložnosti lahko zagotovijo z vidika dobre lokacije in cenovno dostopnih stanovanj.

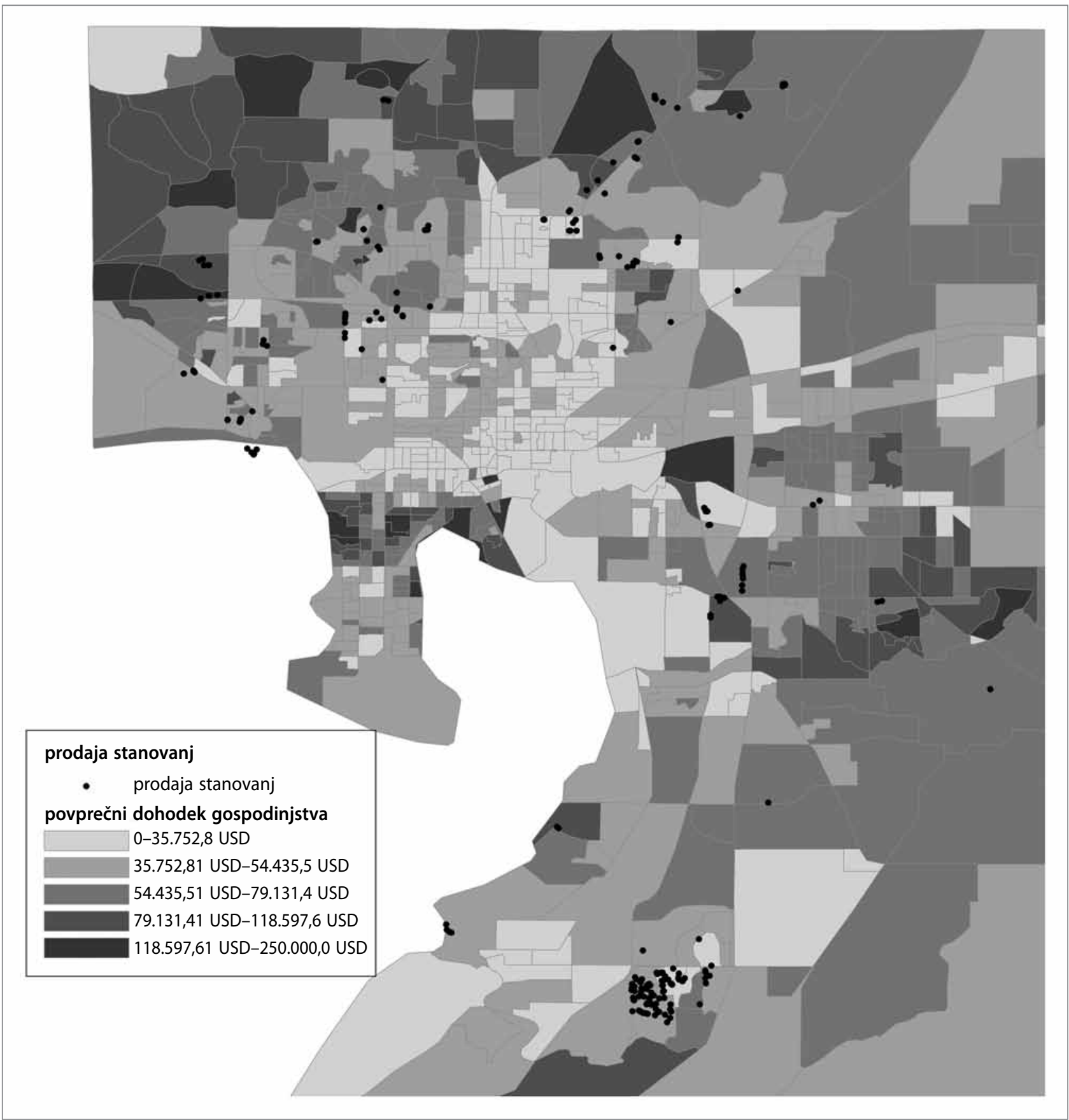

Slika 2: Porazdelitev stanovanjskih transakcij in povprečni dohodek gospodinjstva 


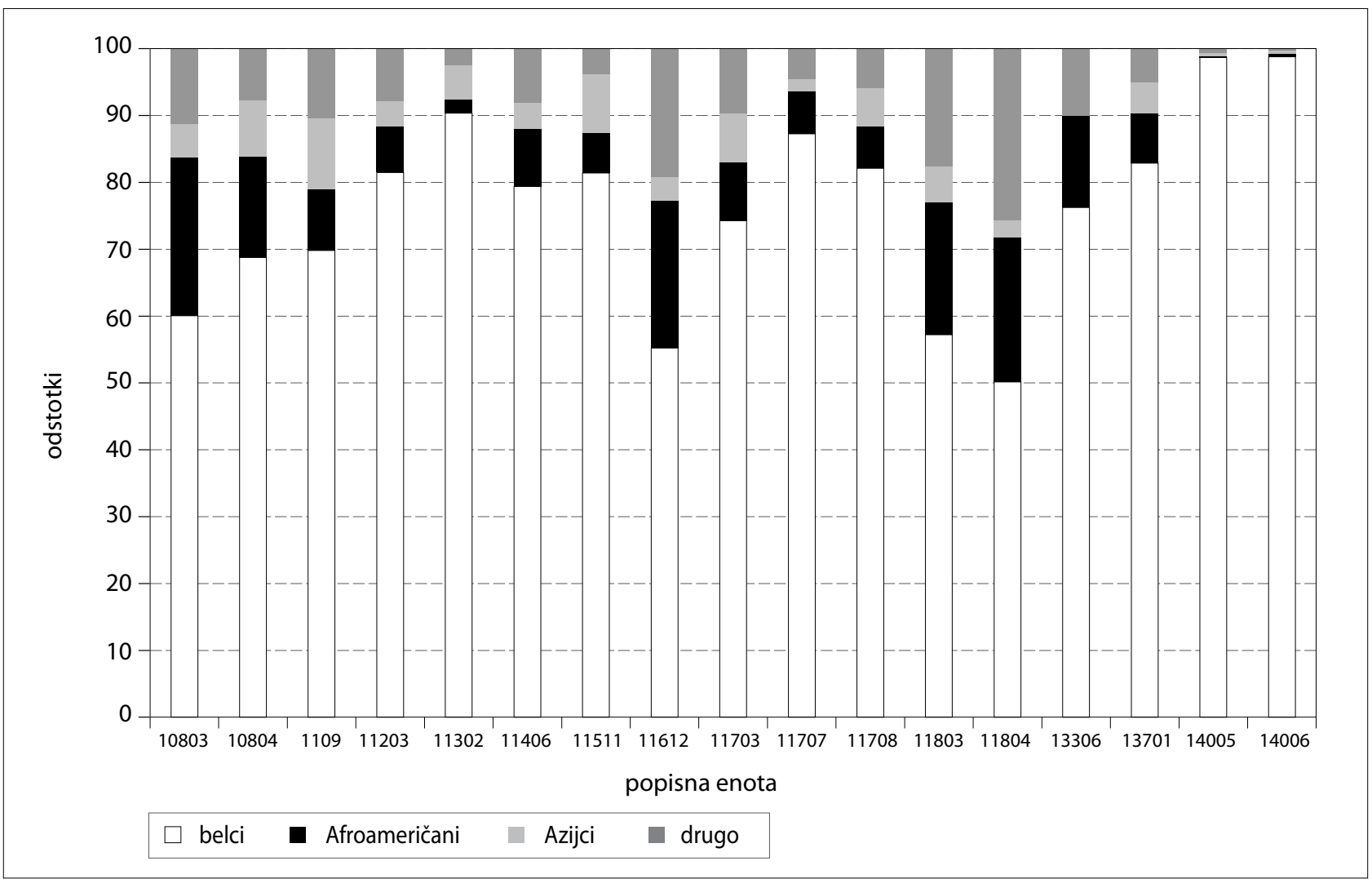

Slika 3: Rasna sestava okrožja Hillsborough na Floridi; enote iz popisa prebivalstva z zaplenjenimi stanovanji, 2008

Rezultati raziskave so pokazali, da je bilo veliko zaplenjenih in nezaplenjenih stanovanj na območjih, na katerih so živeli večinoma belci (ki niso bili latinskoameriškega porekla) s srednje visokimi dohodki (glej sliki 2 in 3), kar se zelo razlikuje od prostorskih vzorcev stanovanjskih zaplemb na splošno. $\mathrm{V}$ literaturi je običajno navedeno, da se zaplembe stanovanj zgoščajo v soseskah, $\mathrm{v}$ katerih živijo manjšine z nizkimi dohodki, zaradi česar se lahko zgodi, da ta stanovanja in soseske brez ustrezne politike in prenove niso zaželena kot vir kakovostnih cenovno dostopnih stanovanj (Apgar in Duda, 2004; Immergluck in Smith, 2006a, 2006b; Belsky, 2008; Bocian idr., 2008; Chan idr., 2010). Po drugi strani pa so lahko zaplembe stanovanj priložnost za dostop do kakovostnih cenovno ugodnih stanovanj tudi brez prenove.

Večina teh stanovanj je blizu mestnega središča in obale. Poleg tega smo ugotovili, da je večina teh blizu postajališč javnega prometa, odprtih prostorov in šol. V primerjavi z drugimi vrstami stanovanjskih objektov so ta stanovanja razmeroma nova. Vse te lastnosti kažejo, da imajo zaplenjena stanovanja določen potencial $\mathrm{v}$ vse večjem fondu cenovno ugodnih stanovanj.

Leta 2009 je AMI v okrožju Hillsborough znašal 54.400 USD. Od 258 zaplenjenih domov jih je bilo 210 prodanih po 130.560 USD ali manj, kar je približno trikrat več od priporočenih 80 \% AMI, kolikor naj bi znašali stanovanjski stroški.
To pomeni, da so si gospodinjstva z 80 \% AMI ali manj lahko privoščila $81,4 \%$ teh stanovanj. Nato smo izračunali mesečne stanovanjske stroške in preučili, kako si jih gospodinjstva $\mathrm{z}$ različno stopnjo prihodka lahko privoščijo. Izračunani mesečni stanovanjski stroški zajemajo hipoteko (glavnica, obresti, davki in zavarovanje), skupne stroške zgradbe in letne stroške vzdrževanja. Mesečni znesek hipoteke smo izračunali na podlagi 80-odstotnega razmerja med posojilom in vrednostjo zastavljenih nepremičnin, 6-odstotne letne obrestne mere in 30-letnega hipotekarnega posojila. Po stanovanjski recesiji je mnogo hipotekarnih upnikov za stanovanja na Floridi zahtevalo vsaj 20-odstotno predplačilo glede na vrednost nepremičnine. Davki na nepremičnine so bili nato določeni na podlagi povprečnih davkov, plačanih v okrožju. $\mathrm{V}$ povprečju so lastniki nepremičnin plačali 16,33 USD na 1.000 USD ocenjene vrednosti nepremičnine. To razmerje smo pomnožili z ocenjeno vrednostjo stanovanj in izračunali letne davke na nepremičnine. Zavarovalne premije proti naravnim nesrečam se med domovi močno razlikujejo zaradi različnih lastnosti stanovanj. Povprečna zavarovalna premija proti ujmam za hišo v vrednosti 150.000 USD je v okrožju Hillsborough znašala 2.135 USD brez olajšave za odpornost proti vetru oziroma 1.528 USD $s$ to olajšavo (Shop and Compare Rates, 2010). Za izračun zavarovalnih premij za stanovanja $\mathrm{v}$ večstanovanjskih zgradbah smo uporabili povprečje 1.831 USD za hišo v vrednosti 150.000 USD. Nato smo predvideli, da so skupni letni stroški 


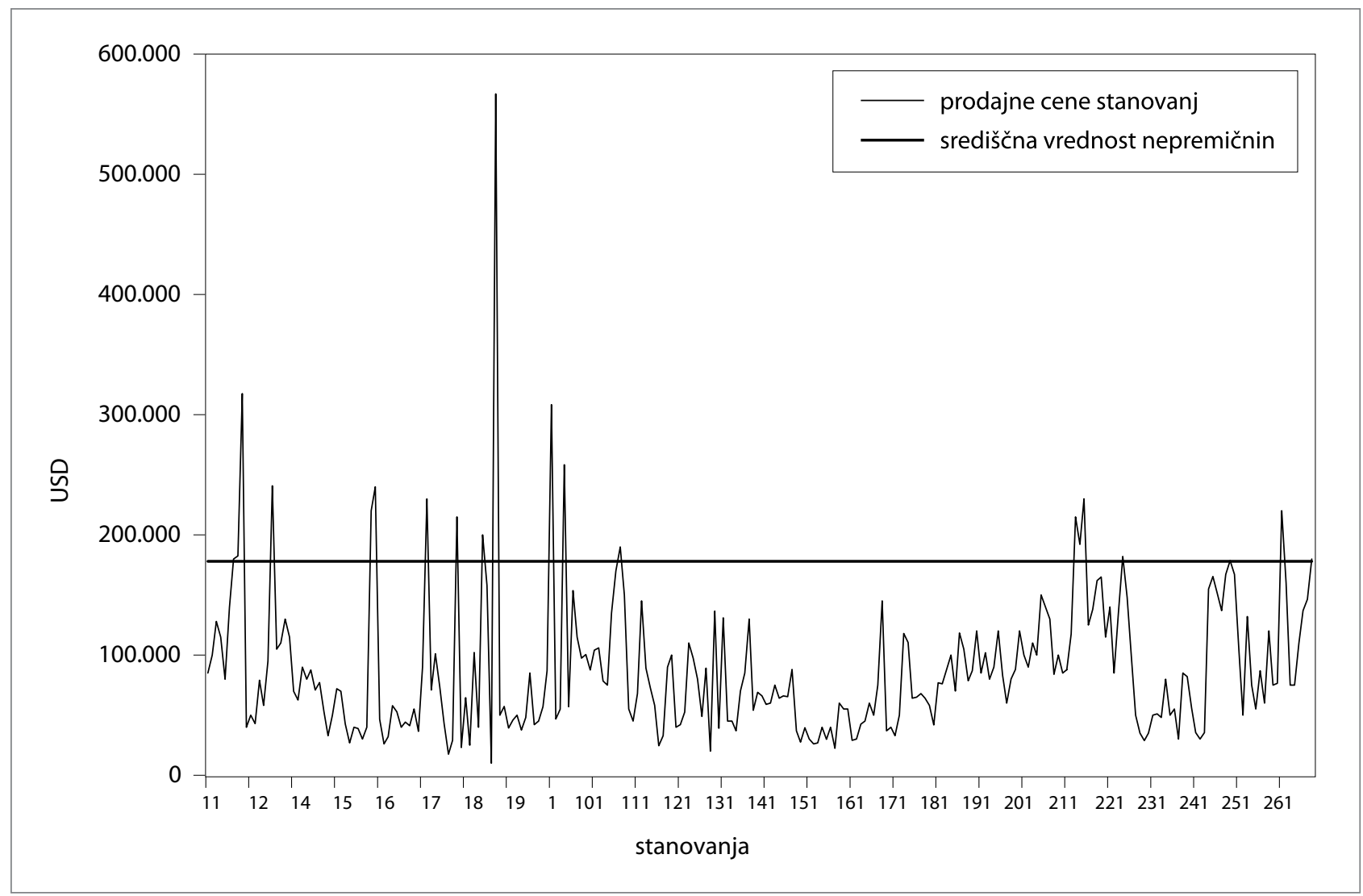

Slika 4: Cene nepremičninskih transakcij v primerjavi s povprečno vrednostjo nepremičnin v okrožju Hillsborough leta 2009 (v USD)

zgradbe znašali 1.000 USD, vendar so bili dejansko lahko še večji. Ocenjeni letni stroški vzdrževanja so znašali približno 500 USD.

Na podlagi izračunov cenovne dostopnosti stanovanj smo ugotovili, da je bilo med 258 zaplenjenimi stanovanji 84,4 \% cenovno dostopnih za gospodinjstva z 80 \% AMI (glej preglednico 6) in zlasti za gospodinjstva z AMI med 30 in $80 \%$ (glej preglednico 6 in sliko 5), s čimer se je povečala zaloga cenovno dostopnih stanovanj za gospodinjstva $\mathrm{z}$ nizkimi do srednje visokimi dohodki. Gospodinjstva z izredno nizkimi dohodki bodo verjetno še vedno potrebovala subvencije, da si bodo lahko privoščila ta stanovanja. Samo približno 3,9 \% zaplenjenih stanovanj je bilo primerno samo za gospodinjstva $z$ več kot 120 \% AMI. Ni nujno, da je bil ta vzorec značilen

Preglednica 6: Zaloga stanovanj v okrožju Hillsborough glede na povprečni dohodek območja (AMI)

\begin{tabular}{lll}
\hline Dohodek & $\begin{array}{l}\text { Število cenovno } \\
\text { dostopnih stanovanj }\end{array}$ & $\begin{array}{l}\text { Dostopna } \\
\text { stanovanja (\%) }\end{array}$ \\
\hline$>120 \%$ AMI & 10 & 3,9 \\
\hline $100-120 \%$ AMI & 7 & 2,7 \\
\hline $80-100 \%$ AMI & 23 & 8,9 \\
\hline $50-80 \%$ AMI & 85 & 32,9 \\
\hline $30-50 \%$ AMI & 103 & 39,9 \\
\hline$<30 \%$ AMI & 30 & 11,6 \\
\hline
\end{tabular}

za vsa zaplenjena stanovanja na Floridi, vendar so v okrožju Hillsborough ta stanovanja povečala zalogo cenovno dostopnih stanovanj. Poleg tega je bila prodajna cena večine teh stanovanj nižja od središčne vrednosti nepremičnin v okrožju (glej sliko 4). Vse to je prispevalo $\mathrm{k}$ njihovi veliki cenovni dostopnosti.

\section{4 Študije sosesk}

Kvantitativno analizo smo dopolnili s kvalitativno analizo, $s$ katero smo preučili, kako bi lahko zaplenjena stanovanja postala vir cenovno ugodnih stanovanj. Osredotočili smo se na štiri stanovanjske soseske: Somerset Park, Enclave at Richmond Place, Brookfield in Maplewood. ${ }^{[8]}$ Somerset Park se nahaja približno $15 \mathrm{~km}$ severovzhodno od Tampe. Gre za sosesko s povprečnim dohodkom 21.000 USD (preglednica 7). Richmond Place se nahaja približno $23 \mathrm{~km}$ severovzhodno od Tampe in ima nekoliko višsi povprečni dohodek na gospodinjstvo, vrednosti nepremičnin pa so raznovrstnejše. Soseski Brookfield in Maplewood se nahajata druga blizu druge, in sicer približno $30 \mathrm{~km}$ vzhodno od Tampe. Sta živahni skupnosti odraslih, $\mathrm{v}$ katerih je bila v preučevanem obdobju zabeležena največja prodaja stanovanj (najvišja prodajna cena ni presegla 170.000 USD). Večino stanovanj v teh štirih soseskah si lahko privoščijo družine z manj kot $100 \%$ AMI (54.400 USD). Natančna dodatna analiza teh sosesk, predstavljena v nadalje- 


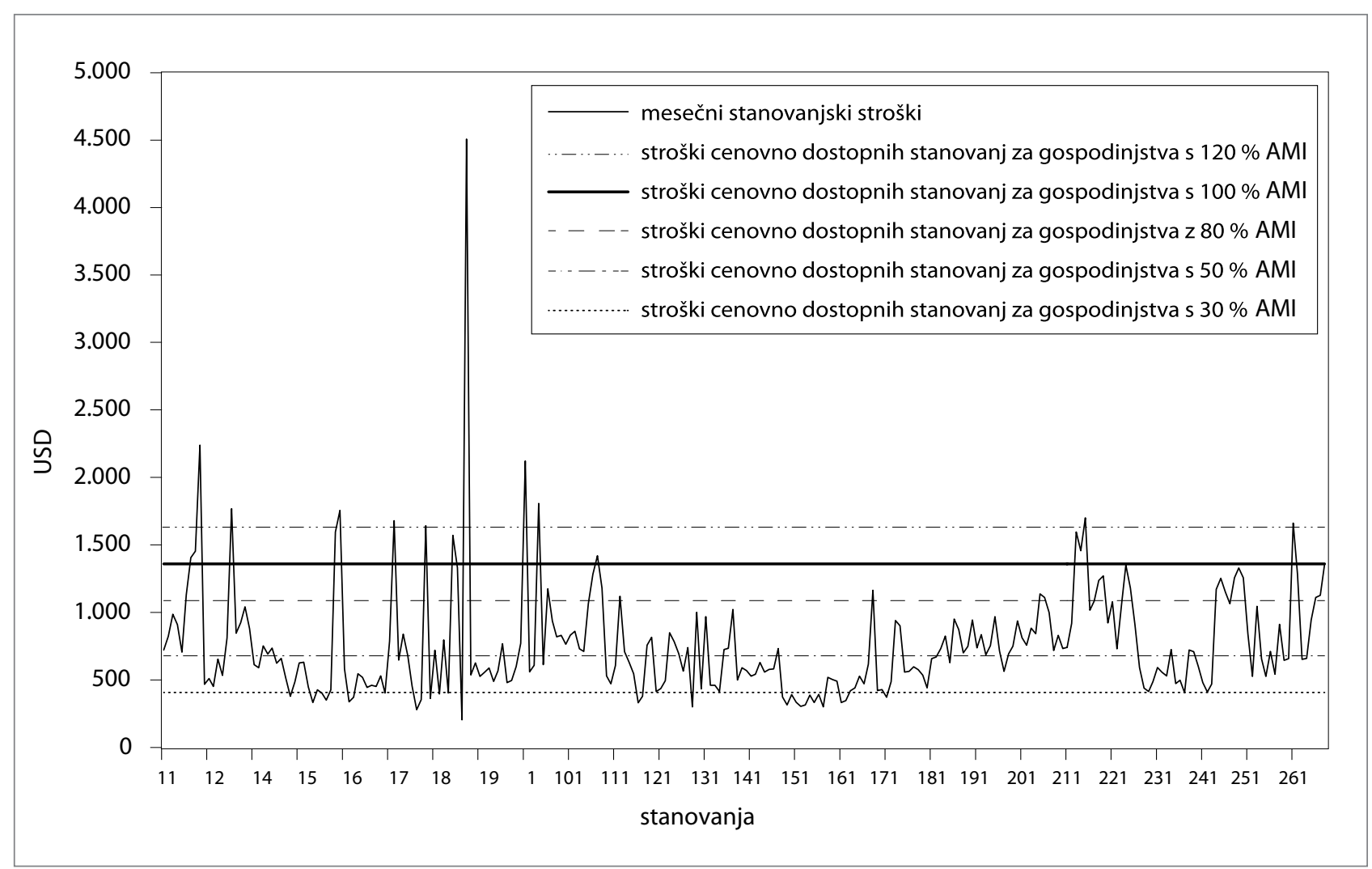

Slika 5: Primerjava mesečnih stanovanjskih stroškov v okrožju Hillsborough in cenovna dostopnost stanovanj za gospodinjstva glede na AMI leta 2009 (v USD)

vanju, se osredotoča na pomembne javne dobrine, ki privlačijo morebitne kupce stanovanj ali najemnike z nizkimi do srednje visokimi dohodki. Te dobrine pomembno izboljšujejo kakovost življenja stanovalcev.

Prva dodatna preučevana lastnost je bila prijaznost soseske do pešcev. Algoritem Walk Score posamezni nepremičnini pripiše oceno prijaznosti do pešcev tako, da izračuna njeno oddaljenost od bližnjih javnih objektov (Walk Score, 2010). Ocena daje informacijo o tem, kako pripravna bi bila lokacija brez uporabe avtomobila (Duncan idr., 2011). Ocena 90-100 pomeni »raj za pešce«, saj stanovalci za dnevne opravke ne potrebujejo avta. Ocena 70-89 pomeni, da je lokacija $\gg$ zelo prijazna pešcem « oziroma da lahko stanovalci veliko stvari opravijo brez avta. Ocena 50-69 pomeni »delno prijazna pešcem « oziroma da lahko stanovalci določene stvari opravijo peš. Ocena 0-49 pomeni, da je lokacija popolnoma »odvisna od avta « oziroma da stanovalci za večino opravkov potrebujejo avto (Walk Score, 2010).

Naslednja dodatna lastnost, ki smo jo preučevali, je bil dostop do javnega prevoza. Poskušali smo določiti progo javnega prometa, ki poteka najbližje posamezni nepremičnini. Nato smo ugotavljali, ali je bila kakšna proga v polmeru $0,8 \mathrm{~km}$ od kompleksa, $s$ čimer smo dobili dihotomno spremenljivko $\mathrm{z}$ vrednostjo da/ne. Okrožje Hillsborough ima javni avtobusni sistem, ki se imenuje The Hillsborough Area Regional Transit Authority.

Pri naslednji dodatni lastnosti, to je kakovost šol, smo za merjenje spremenljivke uporabili oceno šol floridskega ministrstva za šolstvo. Ocenjevanje šol poteka po vsej državi na

Preglednica 7: Opisni statistični podatki najmanjših popisnih enot za izbrane soseske leta 2010

\begin{tabular}{lllllll}
\hline Popisna enota & $\begin{array}{l}\text { Odstotek } \\
\text { belcev }\end{array}$ & $\begin{array}{l}\text { Povprečni dohodek } \\
\text { gospod. (USD) }\end{array}$ & $\begin{array}{l}\text { Povprečna cena } \\
\text { stanovanja (USD) }\end{array}$ & $\begin{array}{l}\text { Povprečno leto } \\
\text { gradnje }\end{array}$ & $\begin{array}{l}\text { Oddaljenost od } \\
\text { posl. sred. (km) }\end{array}$ & $\begin{array}{l}\text { Oddaljenost od } \\
\text { obale (km) }\end{array}$ \\
\hline Somerset & 36,6 & 21.000 & 104.800 & 1980 & 14,81 & 13,68 \\
\hline Richmond & 69,6 & 37.257 & 291.900 & 2004 & 22,69 & 20,60 \\
\hline Brookfield & 97,7 & 32.210 & 178.500 & 2000 & 29,93 & 7,40 \\
\hline Sifield & 97,7 & 32.210 & 178.500 & 2000 & 29,93 & 6,92 \\
\hline
\end{tabular}

Vir: ameriški popisni urad $(2008,2010)$ 
ravni šolskih okrožij pod nadzorom floridskega ministrstva za šolstvo. Kot pri večini šolskih ocenjevalnih lestvic se tudi tu uporablja razpon ocen od $\mathrm{A}$ do $\mathrm{F}$, pri čemer je A najvišja in $\mathrm{F}$ najnižja ocena (ocene $\mathrm{E}$ ni). Ocene šol temeljijo na točkah, ki jih učenci dosežejo na splošnem državnem preverjanju znanja (ang. Florida Comprehensive Assessment Test), odstotku učencev, ocenjenih na tem preverjanju, in merilih ustreznega letnega napredka, določenih $\mathrm{v}$ ameriškem zakonu o vzgoji in izobraževanju (ang. No Child Left Behind Act). Floridsko ministrstvo za šolstvo ocene vseh floridskih šol letno objavi v poročilih o kakovosti šol (ang. school accountability reports), ki so javno dostopna na spletni strani ministrstva. Za analizo smo uporabili zadnjo oceno (za šolsko leto 2008/09), ki je bila na voljo med raziskavo. Kot spremenljivko kvalitativne ocene smo upoštevali tudi podatke o AMI.

\subsection{Empirične ugotovitve o dodatnih lastnostih}

V preglednici 8 so prikazane empirične ugotovitve o dodatnih lastnostih izbranih enot. Najprej smo ugotovili, da so imeli vsi štirje preučevani kompleksi klubske prostore, bazene, teniška igrišča in druge objekte za rekreacijo. Vsi so imeli prosta parkirna mesta, vendar je bil samo en kompleks (Somerset) v bližini avtobusnega postajališča (ki ni bilo oddaljeno več kot $0,8 \mathrm{~km}$ ). Somerset je poleg tega ponujal najcenejša stanovanja. $\mathrm{Z}$ vidika prijaznosti pešcem sta bila dva kompleksa nad povprečjem okrožja, dva pa močno pod povprečjem $(0 / 100)$. Noben pa ni bil med najboljšimi desetimi odstotki v okrožju. Somerset in Richmond sta dosegla več kot $60 \%$, kar pomeni, da sta območji delno prijazni do pešcev in da se lahko stanovalci načeloma odpravijo po določenih opravkih peš. Območje Sun City Center pa je bilo odvisno od avta in glede na oceno prijaznosti pešcem je bilo le nekaj javnih objektov dovolj blizu, da bi se stanovalci lahko do njih odpravili peš.

Kakovost šol je bila različna. Nižji razredi osnovne šole (ang. elementary schools) so bili vsi ocenjeni z A, višji razredi osnovne šole (ang. middle schools) so bili ocenjeni z A ali s $\mathrm{C}$, vse srednje šole pa so bile ocenjene $s$ C. Zanimivo je, da so imele šole $\mathrm{v}$ bližini cenejših stanovanj višje ocene kot tiste $\mathrm{v}$ bližini dražjih stanovanj.
Za izračun mesečnih stroškov na stanovanje smo uporabili 30-letno fiksno hipoteko s 6,5-odstotno obrestno mero. ${ }^{[9]}$ Pri znesku 50.000 USD bi to zneslo približno 336,87 USD, prišteti pa moramo še davke in zavarovanje (Mortgage Calculator, 2010). To pomeni, da bi tudi pri najvišjih ocenjenih skupnih stroških zgradbe oziroma soseske mesečni stanovanjski stroški znašali manj kot povprečne najemnine na tem območju (ki so leta 2008 znašale 900 USD na primerljivo stanovanje).

HUD priporoča, da gospodinjstva za svoje stanovanje ne porabijo več kot 30 \% letnega dohodka in tako tudi pri najvišje ocenjenih hipotekah in skupnih stroških mesečni stroški cenejših stanovanj v Somersetu in Richmondu niso presegali 30 \% povprečnih prihodkov gospodinjstev na tem območju (HUD, 2010). Poleg tega so bili stroški, povezani s prodajo zaplenjenih stanovanj v Somersetu in Richmondu, izrazito nižji od povprečnih stroškov stanovanj v vzorcu (89.628 USD) in tudi nižji od povprečnih stanovanjskih stroškov na tem območju nasploh (297.943 USD).

Najcenejše stanovanje v Somersetu je imelo najvišjo oceno prijaznosti do pešcev, najbolje ocenjene šole, hkrati pa je bil ta kompleks edini, ki je bil blizu postajališču javnega prometa (in imel dovolj prostih parkirnih mest) in najbližje poslovnemu središču (čeprav noben kompleks ni zelo blizu središču ali obali). Somerset je bil obenem najstarejši in najmanjši kompleks. Poudariti je treba, da velikost soseske do neke mere določa vrsto gospodinjstva, za katero so ta stanovanja primerna.

\subsection{Značilnosti sosesk}

Zračni posnetki so nam pomagali kvalitativno oceniti splošne značilnosti kompleksov in sosesk. Najprej smo preučili urbane lastnosti območja, in sicer smo kvalitativno ocenili rabo tal v soseski. Večina območij s stanovanjsko rabo je bila v predmestjih, večina območij z mešano rabo tal pa $\mathrm{v}$ mestih. Vsako fotografijo smo ocenili na lestvici od 1 do 5 , pri čemer se je ocena 5 nanašala na najbolj mestna območja (z mešano rabo tal). Upoštevali smo tudi okolico in nato ocenili kompleks. Vrsta kompleksa je bila opisna oznaka, na primer »več manjših zgradb « ali »stolpnica «. Vključili smo tudi parkirišča ob

Preglednica 8: Dodatne empirične ugotovitve za izbrane soseske

\begin{tabular}{lllll}
\hline Spremenljivka & Somerset & Richmond & Brookfield & Sifield \\
\hline javni objekti & da & da & da & da \\
\hline prijaznost pešcem* & $68 / 100$ & $65 / 100$ & $0 / 100$ & $0 / 100$ \\
\hline javni prevoz v polmeru 0,8 km & da & ne & ne & ne \\
\hline kakovost nižjih razredov osnovne šole & $\mathrm{A}$ & $\mathrm{A}$ & $\mathrm{A}$ & $\mathrm{A}$ \\
\hline kakovost višjih razredov osnovne šole & $\mathrm{A}$ & $\mathrm{A}$ & $\mathrm{C}$ & $\mathrm{C}$ \\
\hline kakovost srednje šole & $\mathrm{C}$ & $\mathrm{C}$ & $\mathrm{C}$ & $\mathrm{C}$ \\
\hline
\end{tabular}

Opombe: $\left(^{*}\right)$ povprečje okrožja $=60 / 100 ;$ najboljših $10 \%$ okrožja $=85-100$. 

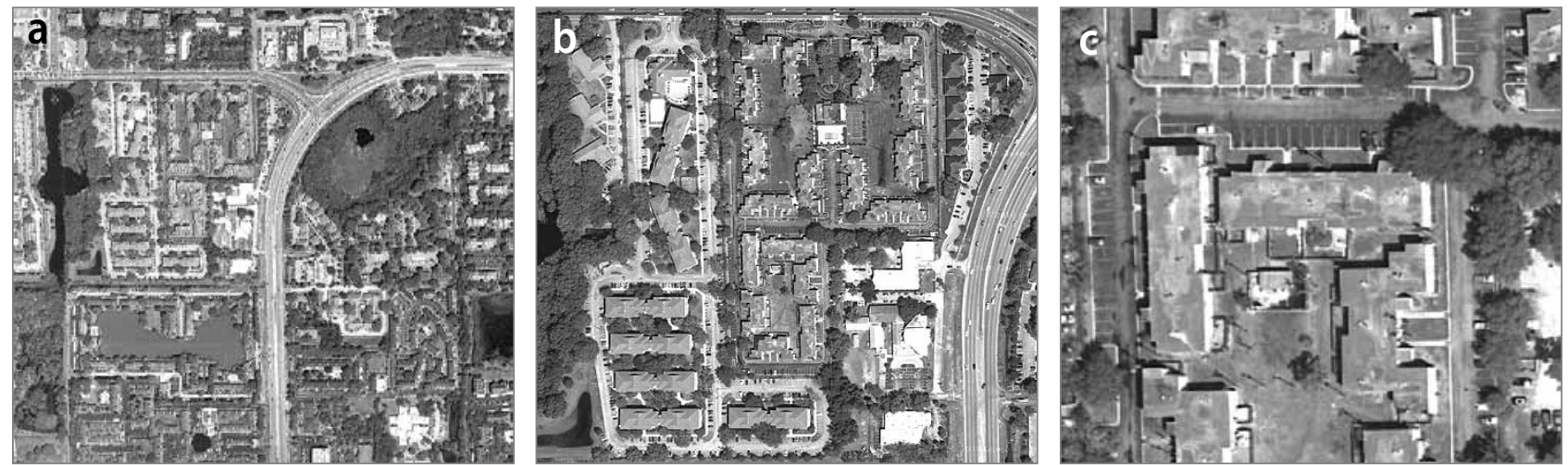

Slika 6: Somerset: (a) soseska, (b) kompleks in (c) zgradbe, zračni posnetki (vir: zemljevidi Google, 2010)
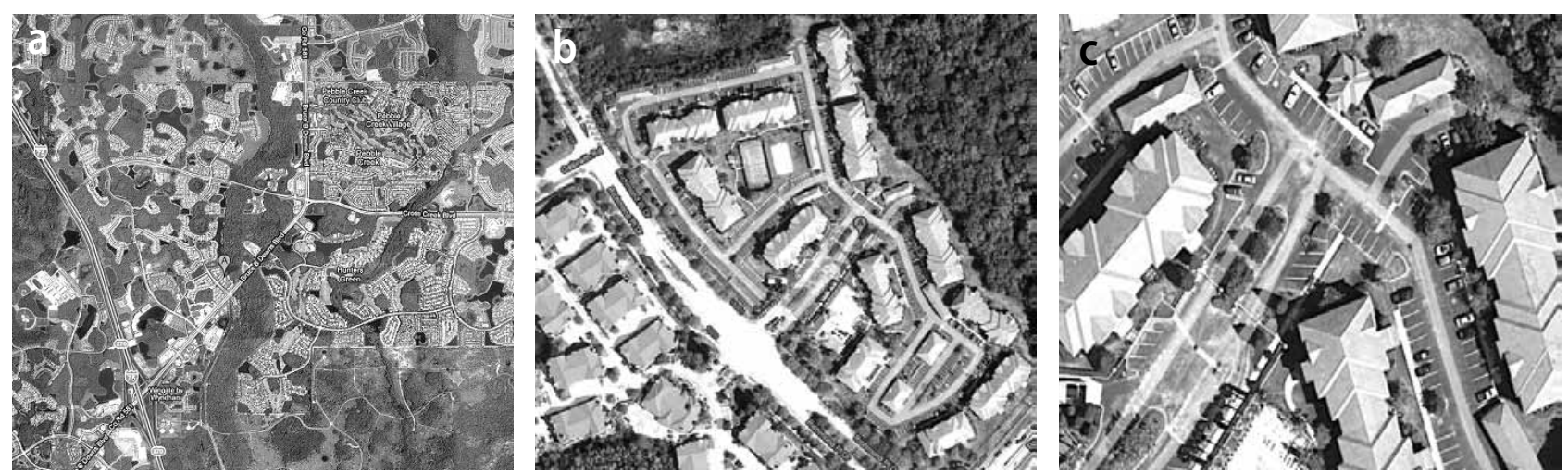

Slika 7: Richmond: (a) soseska, (b) kompleks in (c) zgradbe, zračni posnetki (vir: zemljevidi Google, 2010)
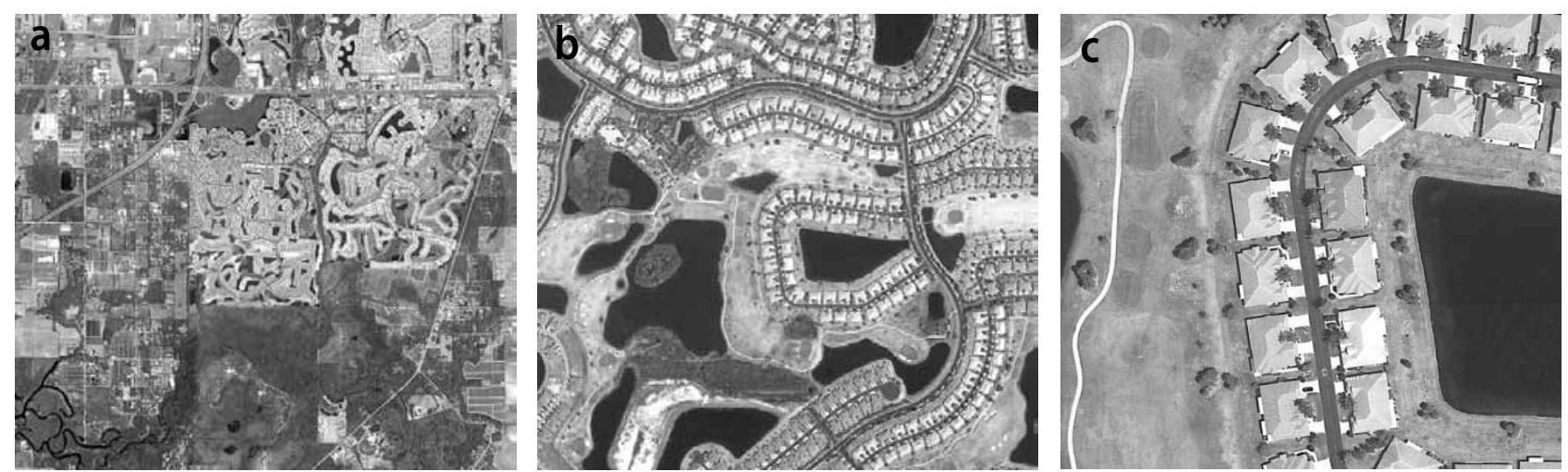

Slika 8: Brookfield: (a) soseska, (b) kompleks in (c) zgradbe, zračni posnetki (vir: zemljevidi Google, 2010)
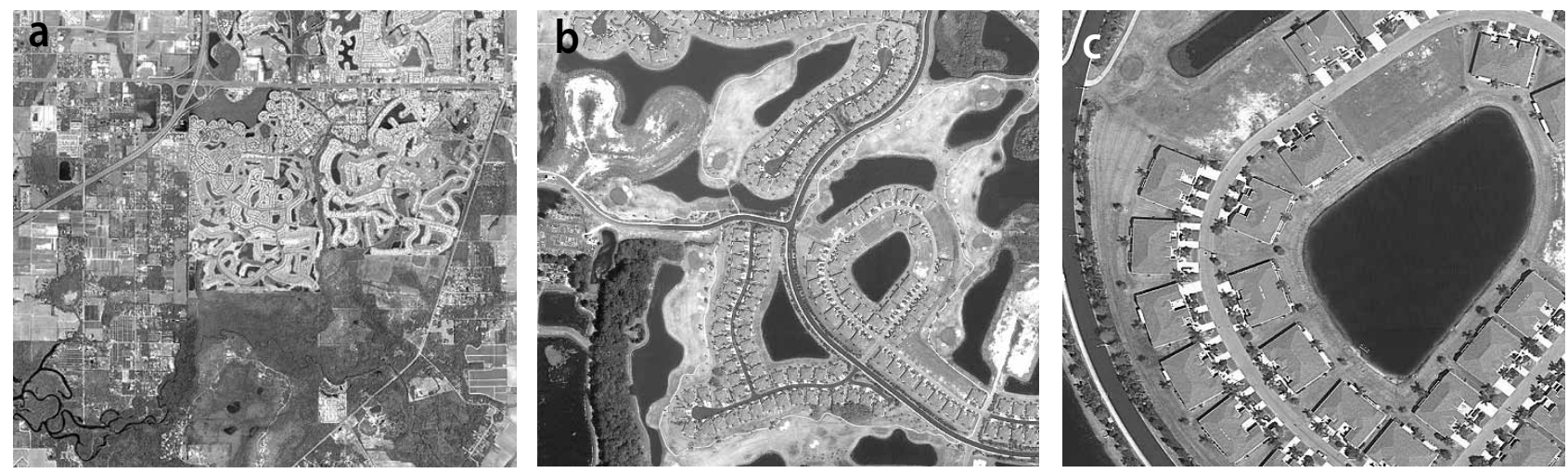

Slika 9: Sifield: (a) soseska, (b) kompleks in (c) zgradbe, zračni posnetki (vir: zemljevidi Google, 2010) 
Preglednica 9: Ugotovitve na podlagi zračnih posnetkov izbranih sosesk

\begin{tabular}{lllll}
\hline Spremenljivka & Somerset & Richmond & Brookfield & Sifield \\
\hline urbana oblika & 3 & 2 & 1 & 1 \\
\hline vrst kompleksa & več manjših zgradb & več manjših zgradb & več dvojčkov & več dvojčkov \\
\hline parkirna mesta & $\mathrm{da}$ & $\mathrm{da}$ & $\mathrm{da}$ & $\mathrm{da}$ \\
\hline odprt prostor & $\mathrm{da}$ & $\mathrm{da}$ & $\mathrm{da}$ & $\mathrm{da}$ \\
\hline poraslost z drevesi & malo večjih dreves & malo manjših dreves & malo manjših dreves & malo manjših dreves \\
\hline območja interakcije & 4 & 2 & 1 & 1 \\
\hline
\end{tabular}

posameznem kompleksu. Parkirišča so bila dihotomna spremenljivka, ki je pokazala, ali ima kompleks na voljo posebna parkirna mesta za stanovalce. Poleg tega smo ocenili tudi odprti prostor. Šlo je za dihotomno spremenljivko, ki je pokazala, ali se kompleks stika $\mathrm{z}$ odprtim prostorom oziroma nahaja $\mathrm{v}$ njegovi bližini (na primer čez cesto). Nato smo izmerili še poraslost $\mathrm{z}$ drevesi, pri čemer smo ocenili število dreves v kompleksu; to smo ocenili na lestvici od 1 do 5 , pri čemer je ocena 5 pomenila skoraj popolno prekritost $\mathrm{z}$ drevesi, ocena 1 pa skoraj nič senčnih območij. Na koncu smo preučili še morebitna območja interakcije, na katerih so stanovalci v interakciji s svojimi sosedi (dvorišča, vrtovi, bazeni, teniška igrišča, sprehajalne poti itn.). Spremenljivka ocenjuje priložnosti dostopa do socialnega kapitala. Ocene so se gibale od 1 do 5, pri čemer je ocena 5 pomenila veliko območij interakcije, ocena 1 pa zelo omejeno območje interakcije. Ti podatki so prikazani na slikah $6,7,8$ in 9 in $\mathrm{v}$ preglednici 9.

Pri posameznih merilih so bila najbolje ocenjena cenejša stanovanja, zlasti v Somersetu, saj je bila zanje značilna bolj mešana raba tal (mestna območja), imela so več območij, ki so omogočala družbeno interakcijo, in več večjih dreves ( $s$ tem so ponujala zrelejšo krajinsko estetiko). Žal pa so bili najcenejši kompleksi tudi najgosteje pozidani.

\section{Razprava}

Na podlagi kvantitativnih in kvalitativnih metod preučevanja floridskega okrožja Hillsborough, trga zaplenjenih stanovanj in možnosti predelave teh stanovanj v cenovno dostopna stanovanja smo ugotovili, da so se stanovanja $\mathrm{v}$ postopku zaplembe prodajala po nižji ceni kot stanovanja, ki niso bila v tem postopku. Čeprav je bil padec cene majhen, so bila ta stanovanja še vedno ugodna priložnost za gospodinjstva z različnim AMI. Primeri, ki smo jih kvalitativno ocenili, so pokazali, da bi lahko poleg cenovne ugodnosti ta stanovanja omogočila dostop do javnih dobrin in objektov, kar bi zagotavljalo dobro kakovost življenja z dobrim dostopom do javnega prevoza, visokokakovostnimi osnovnimi šolami, odprtimi prostori v bližini, urbanimi dobrinami in dostopom do socialnega kapitala.
Državna in lokalne vlade bi lahko te podatke uporabile za to, da bi krizo z zaplembami stanovanj izkoristile za reševanje problemov cenovno ugodnih stanovanj v marsikateri skupnosti, zlasti na Floridi. Iskanje načrtovalskih rešitev zajema razprave o nepremičninskem trgu, cenovni dostopnosti, stabilizaciji in okrevanju.

Dejavniki, povezani s ceno stanovanja, kot je oddaljenost od poslovnega središča ali obale, lahko pomagajo določiti območja z ugodnimi cenami stanovanj; ta območja lahko ustvarijo več priložnosti kot druga. Pri spreminjanju lastniških stanovanj $\mathrm{v}$ cenovno ugodna stanovanja pa je treba premostiti veliko ovir na strani ponudbe in povpraševanja. Standarde odobritve hipotekarnih kreditov bi morali prilagoditi gospodinjstvom z nizkimi do srednje visokimi prihodki, financiranje stanovanj pa obravnavati kot konvencionalno financiranje domov. Kot je pokazala analiza, si lahko večino zaplenjenih stanovanj privošcijo gospodinjstva z manj kot $100 \%$ AMI. Tako pri predelavi teh stanovanj v cenovno dostopna stanovanja še vedno ostaja nekaj velikih ovir. Prvič, 20-odstotni polog lahko številnim kupcem onemogoči, da pridobijo ustrezen konvencionalni hipotekarni kredit, čeprav imajo ustrezno kreditno oceno in prihodke. To oviro bi lahko premostili tako, da bi ponudili pomoč pri plačevanju teh pologov ali pa zmanjšali zneske pologov pri hipotekah, ki jih zavaruje država. Drugič, stroški cenovno dostopnih stanovanj, ki smo jih ocenili v analizi, so lahko dejansko višji. Skupni stroški lahko v bolj luksuznih kompleksih znašajo tudi po več sto dolarjev mesečno. Ta problem bi lahko rešili s subvencijami ali z dogovorom med združenjem lastnikov stanovanj in posameznimi lastniki oziroma vlado. Tretjič, število zaplenjenih stanovanj je omejeno, saj je v postopku zaplembe veliko več enodružinskih hiš kot stanovanj. Sedanji državni in zvezni programi, povezani s postopkom zaplembe, so pomagali stabilizirati soseske in zagotovili večjo zalogo cenovno dostopnih stanovanj, vendar je obseg teh programov zelo omejen. Močno združenje različnih agencij bi lahko pomagalo oblikovati inovativne programe financiranja za preoblikovanje zaplenjenih domov v cenovno dostopna stanovanja. Prav tako bi prišle prav subvencije, ki bi zmanjšale skupne stroške stanovanjskih zgradb. 


\section{Sklep}

$\mathrm{V}$ članku je predstavljen prvi primer raziskave nepremičninskih zaplemb v ZDA na podlagi vrst stanovanj in tega, kako bi lahko zaplenjena stanovanja v večstanovanjskih kompleksih uporabili za zagotavljanje cenovno dostopnih stanovanj na Floridi, kjer tovrstna stanovanja sestavljajo velik delež stanovanjskega fonda. Zaradi omejenih podatkov smo za primer vzeli samo okrožje Hillsborough, kar pomeni, da v raziskavo nismo vključili južne Floride, kjer so zaplembe še večji problem in kjer je še več praznih stanovanj kot v okrožju Hillsborough. Prihodnje raziskave bi se morale osredotočiti na širjenje obsega raziskovalnih področij in odkrivanje praznih zaplenjenih stanovanj za morebitno predelavo. Raziskovalno metodologijo bi lahko uporabili v lokalnih skupnostih za izračun zaloge cenovno dostopnih stanovanj. S kvalitativnimi raziskavami pa bi lahko preučevali, ali je »predelava zaplenjenih stanovanj $\mathrm{v}$ cenovno dostopna stanovanja « v New Yorku uspešno spodbudila ponovno uporabo in predelavo praznih nepremičnin, zlasti praznih zaplenjenih stanovanj.

Huston John Gibson

Kansas State University, Faculty of Regional and Community Planning, Department of Landscape Architecture/Regional and Community Planning, Manhattan, Kansas, ZDA

E-pošta: hgibson@k-state.edu

Yanmei Li

Florida Atlantic University, Faculty of Urban and Regional Planning, School of Urban and Regional Planning, Ft. Lauderdale, Florida, ZDA E-pošta: yli22@fau.edu

\section{Opombe}

[1] Podatki so vzeti iz več izdaj četrtletne revije U. S. Housing Market Conditions, ki jo izdaja ameriško ministrstvo za stanovanja in urbani razvoj.

[2] Ta številka temelji na podatkih o indeksu cen stanovanj zvezne agencije za nepremičninske finance.

[3] Leta 2008 je bilo za prvi nakup stanovanja dodeljeno 7.500 USD. Leta 2009 se je znesek povečal na 8.000 USD, poleg tega pa je bilo 6.500 USD dodeljeno za drugi nakup stanovanja. Najprej naj bi davčni odbitek veljal do 30. novembra 2009, pod pritiski nepremičninske industrije pa so ga podaljšali do 30. aprila 2010.

${ }^{[4]} V$ svoji prvotni raziskavi smo iskali tudi podatke o špekulaciji investitorjev oziroma preprodaji nepremičnin po napihnjenih cenah na tem trgu ter kako bi to lahko vplivalo na okrevanje trga. Nič ni potrjevalo, da bi bila velika koncentracija špekulacij in preprodaj povezana $z$ visokimi stroški združenja lastnikov stanovanj, vendar so znani določeni primeri te dejavnosti (na primer Condo Vultures, Inc., na južni Floridi; Depken idr., 2009). Nismo pa imeli na voljo dovolj podatkov o prodajalcih, da bi lahko jasno določili motive kupcev, zato je treba to področje $v$ prihodnosti dodatno raziskati.
[5] Sumljivi in nepopolni podatki niso bili vključeni v analizo.

[6] Po ocenah ameriškega popisnega urada (2010) je v okrožju Hillsborough živelo nekaj več kot milijon ljudi (1.195.317 v celotnem okrožju leta 2009 in 332.888 v Tampi leta 2006).

[7] Obdobje od januarja do maja velja na Floridi za visoko sezono. Zaradi prijetnega vremena živi veliko prebivalcev na Floridi samo v tem obdobju (pravijo jim »ptice selivke«). Posledično so plaže, ceste, restavracije in večstanovanjski objekti takrat veliko bolj natlačeni kot v nizki sezoni (od junija do decembra).

${ }^{[8]}$ Soseski Brookfield in Maplewood sta skupnosti v okrožju Hillsborough, katerih stanovalci so starejši od 55 let. To smo izvedeli šele po tem, ko smo ju naključno izbrali za svojo študijo primera. Odločili smo se ju obdržati v raziskavi, saj smo s tem želeli predstaviti dodatno omejitev za družine, ki potrebujejo cenovno dostopno stanovanje, in ker gospodinjstva s starejšimi člani prav tako potrebujejo cenovno dostopna stanovanja.

[9] Obrestne mere nihajo, vendar se nam je po pogovoru s strokovnjakom za hipotekarne kredite 27. aprila 2010 5,6-odstotna obrestna mera zdela primerna za oceno standardnih odplačil kreditov, merjenih v vrednosti dolarja leta 2008.

\section{Viri in literatura}

Allen, M. T., in Swisher, J. (2000): An analysis of the price formation process at a HUD auction. Journal of Real Estate Research, 20(3), str. 279-298.

Ameriški popisni urad (2008): State and county quickfacts. Dostopno na: http://quickfacts.census.gov (sneto 4. 6. 2010).

Ameriški popisni urad (2010): American FactFinder. Dostopno na: http://factfinder2.census.gov (sneto 10. 8. 2012).

Anderson, B. (2009). When could empty condos become affordable housing? City Limits, 7. 6. 2009. Dostopno na: http://www.indypressny. org (sneto 8. 1. 2010).

Apgar, W., in Duda, M. (2004): Mortgage foreclosure trends in Los Angeles: Patterns and policy issues. Los Angeles, Neighborhood Housing Services.

Belsky, E. S. (2005): Revisiting rental housing: A policy summit. Harvard University, Joint Center for Housing Studies, Framing the Rental Policy Summit.

Betances, Y. (2010): Foreclosed Buildings to Become Affordable Homes. Eagle Tribune. 15. 7. 2010. Dostopno na: http://www.eagletribune.com (sneto 15. 7. 2010).

Bocian, D. G., Ernst, K. S., in Li, W. (2008): Race, ethnicity and subprime home loan financing. Journal of Economics and Business, 60(1-2), str. 110-124. DOI: 10.1016/j.jeconbus.2007.10.001

Carr, J. H. (2008): Responding to the foreclosure crisis. Washington DC, National Community Reinvestment Coalition.

Carroll, T. M., Clauretie, Y. M, Neil, H., in Jorgensen, C. (1995): HUD versus private bank foreclosures: A spatial and temporal analysis. Journal of Housing Economics, 4(2), str. 183-94. DOI: 10.1006/jhec.1995.1009

Chan, S., Gedal, M., Been, V., in Haughwout, A. (2010): The role of neighborhood characteristics in mortgage default risk: evidence from New York City. New York, New York University, Wagner School and Furman Center for Real Estate \& Urban Policy.

Davies, M. A. (2010): Reflections on the foreclosure crisis. Land Lines, julij, str. 1-8. 
Depken, C. A., Hollans, H., in Swidler, S. (2009): An empirical analysis of residential property flipping. Journal of Real Estate Finance and Economics, 39(3), str. 248-263. DOI: 10.1007/s11146-009-9181-3

Duncan, D. T., Aldstadt, J., Whalen, J., Melly, S. J., in Gortmaker, S. L. (2011): Validation of walk score for estimating neighborhood walkability: An analysis of four US Metropolitan Areas. International Journal of Environmental Research and Public Heath, 8(11), str. 4160-4179. DOI: $10.3390 /$ ijerph 8114160

Floridska klirinška hiša za nepremičninske informacije (2010): Households by income and cost burden, Hillsborough County, 2009. Dostopno na: http://flhousingdata.shimberg.ufl.edu (sneto 15 8. 2011).

Foote, C., Gerardi, K., Goette, L., in Willen, P. (2010): Reducing foreclosures: no easy answers. NBER Macroeconomics Annual, 24(1), str. 89-138.

Forgey, F. A., Rutherford, R. C., in Van Buskirk, M. L. (1994): Effect of foreclosure status on residential selling price. Journal of Real Estate Research, 9(3), str. 313-318.

Gerrity, M. (2010): Miami condo investors successfully resell 400 condo foreclosures, making USD 83 per foot profit. 22. 3. 2010. Dostopno na: http://www.realestatechannel.com (sneto 15. 8. 2011).

Hardin, W.G. III, in Wolverton, M. L. (1996): The relationship between foreclosure status and apartment price. The Journal of Real Estate Research, 12(1), str. 101-109.

Harding, J. P., Rosenblatt, E., in Yao, V. W. (2009): The contagion effect of foreclosed properties. Journal of Urban Economics, 66(3), str. 164-178. DOI: 10.1016/j.jue.2009.07.003

House Repos (2009): Foreclosed condos converted into affordable homes in New York City. Dostopno na: http://www.houserepos.net (sneto 20. 7. 2009).

Immergluck, D., in Smith, G. (2006a): The external costs of foreclosure: The impact of single-family foreclosures on property values. Housing Policy Debate, 17(1), str. 57-79. DOI: 10.1080/10511482.2006.9521561

Immergluck, D., in Smith, G. (2006b): The impact of single family mortgage foreclosures on neighborhood crime. Housing Studies, 21(6), str. 851-866. DOI: 10.1080/02673030600917743

Katz, A. (2009): Gentrification hangover: How New York could create affordable housing from its empty glass condo buildings and failed takeover projects. Prospect, 18. 12 2009. Dostopno na: http://www. prospect.org (sneto 6. 1. 2010).

Lin, Z., Rosenblatt, E., in Yao, V. W. (2009): Spillover effects of foreclosures on neighborhood property values. Journal of Real Estate Finance Economics, 38(4), str. 387-407. DOI: 10.1007/s11146-007-9093-z

Mehaffy, M. W., in Haas, T. (2012): Poststrukturalisti križem rok opazujejo svet v plamenih: izhod iz samoustvarjene krize »arhitekturne kulture«. Urbani izziv, 23(1), str. 5-15. DOI: 10.5379/urbani-izziv-2012-23-01-001

Ministrstvo za stanovanja in urbani razvoj (2010): Affordable housing. Dostopno na: www.hud.gov (sneto 27. 1. 2010).

Mortgage Calculator (2010): Mortgage calculator. Dostopno na: http:// www.mortgagecalculator.org (sneto 27. 6. 2010).

Nacionalno združenje nepremičninskih posrednikov (2012): Housing affordability index. Dostopno na: http://www.realtor.org (sneto 24. 7. 2012).

Nelson, K. P. (1994): Whose shortage of affordable housing? Housing Policy Debate, 5(4), str. 401-442. DOI: 10.1080/10511482.1994.9521172

Padgett, T. (2009): Despite the crash in prices, affordable housing still lacking. Time, 25. 2. 2009. Dostopno na: http://www.time.com (sneto 15.8 .2011 ).
Pennington-Cross, A. (2003): Credit history and the performance of prime and nonprime mortgages. Journal of Real Estate Finance and Economics, 27(3), str. 279-301. DOI: 10.1023/A:1025891223226

Poethig, E. (2010): The impact of the foreclosure crisis on public and affordable housing in the Twin Cities. Washington DC, US Department of Housing and Urban Development, Policy Research and Development.

Realtytrac (2008): U.S. foreclosure market statistics by state. Dostopno na: http://www.realtytrac.com (sneto 31. 1. 2010).

Schuetz, J., Been, V., in Ellen, I. G. (2008): Neighboring effects of concentrated foreclosures. Journal of Housing Economics, 17(4), str. 306319. DOI: 10.1016/j.jhe.2008.09.004

Shilling, J. D., Benjamin, J. D., in Sirmans, C. F. (1990): Estimating net realizable value for distressed real estate. The Journal of Real Estate Research, 5(1), str. 129-140.

Shop and Compare Rates (2010): Compare rates: Auto, home, life, mortgage and refinance. Dostopno na: www.shopandcomparerates.com (sneto 4. 6. 2010).

Springer, T. M. (1996): Single-family housing transactions: Seller motivations, price, and marketing time. Journal of Real Estate Finance and Economics, 13(3), str. 237-254. DOI: 10.1007/BF00217393

Walk Score (2010): City and neighborhood walkability rankings. Dostopno na: http://www.walkscore.com (sneto 4. 6. 2010).

Wallison, P. J. (2009): Cause and effect: Government policies and the financial crisis. Critical Review, 21(2), str. 365-376. DOI: 10.1080/08913810902934158

White, J. (2009): First-time homebuyer tax credit: Testimony on taxpayers use of the credit and implementation and compliance challenges. Washington DC, US Government Accountability Office.

Zemljevidi Google (2010): Map of Tampa/Hillsborough County, Florida. Dostopno na: http://maps.google.com (sneto 27. 6. 2010).

Zveza za pravico do mesta (2010): People without homes and homes without people: A count of vacant condos in select NYC neighborhoods 2010. New York. 